\title{
Muscarinic receptor functioning and distribution in the eye: molecular basis and implications for clinical diagnosis and therapy
}

GREGOR W. NIETGEN, JOERG SCHMIDT, LUTZ HESSE, CHRISTIAN W. HÖNEMANN, MARCEL E. DURIEUX
The role of neurotransmitters has generated considerable interest over the last decade. Dale's first description in 1914 of the muscarinic and nicotinic components of the cholinergic system ${ }^{1}$ provided an explanation for the effects of various cholinergic active drugs on the eye. Parasympathetic cholinergic input to the human iris sphincter muscle comes from neurons whose axons make up the ciliary nerve, a branch of the third cranial nerve. Acetylcholine is released by these neurons onto their target cells, the smooth muscle surrounding the pupil. Muscarinic acetylcholine receptors on the surface of the muscle cells transduce the chemical signal into a muscle contraction which constricts the pupil. It has also been shown that muscarinic cholinergic receptors exist in the mammalian iris dilator muscle, once thought to receive only noradrenergic input from the sympathetic system. ${ }^{2}$ This double reciprocal innervation of the iris sphincter follows the general pattern of innervation: stimulation of the parasympathetic nervous system (cholinergic muscarinic), which functions through the polyphosphoinositide signalling pathway, leads to contraction. Relaxation is a result of the activation of the sympathetic nervous system (beta-adrenergic), which functions through the cAMP system.

The active secretion of aqueous humour is carried out by the ciliary epithelium and is therefore a key target for regulation by endogenous regulators and anti-glaucoma drugs. Histological evidence indicates that the ciliary processes receive innervation by both sympathetic and parasympathetic nerves. Further on, ciliary epithelial cells have been demonstrated to contain both adrenergic and cholinergic receptors. ${ }^{3}$ Interactions between the two second messenger systems are important in regulation of smooth muscle tone and are an important focal point for pharmacological manipulation. ${ }^{4}$ Besides these well-established functions of the ocular receptor interplay a vast number of receptors (cholinergic, adrenergic and others) have been found in all types of ocular tissue: the functional consequence of their activation remains elusive but is currently being investigated with great zeal. Glaucoma patients are still being treated with pilocarpine almost 40 years ${ }^{5}$ after its introduction to western medicine in $1875 .^{6}$ The development of specific muscarinic agonists (acetyl- $\beta$-methylcholine) and antagonists (scopolamine) followed. Cholinesterase was discovered in $1926^{7}$ and named in $1932 .{ }^{8}$ At the same time carbachol was synthesised, ${ }^{9}$ a drug resistant to cholinesterases with a suitable specificity for glaucoma treatment. ${ }^{10,11}$ Over the years various compounds have been investigated regarding their potential to lower intraocular pressure (IOP), the most prominent pathophysiological feature of glaucoma. The majority of these substances do not affect the muscarinic system of the eye and intervene at different receptor sites.

The ciliary muscle, focus of intense investigation, contracts through activation of muscarinic receptors. Due to its insertion into the trabecular meshwork it increases aqueous outflow facility, thereby reducing IOP. ${ }^{12,13} \mathrm{~A}$ variety of drugs can also reduce IOP, yet by very different mechanisms of action. This indicates the pathogenetic complexity of glaucoma, with its multiple possible causes; however, IOP regulation through the muscarinic signalling system appears to be an important component. The ocular muscarinic receptor system is not dedicated solely to the maintenance of pressure homeostasis though. A wide distribution of these receptors in the human eye has been found. Muscarinic signalling is involved in signal transduction functions of the retina, ${ }^{14}$ possibly in reparative functions in the corneal and lenticular tissue, ${ }^{15,16}$ and appears to play a major role in the embryonic and postnatal development of the eye. ${ }^{17}$ The main distinction between

\author{
G.W. Nietgen \\ J. Schmidt \\ L. Hesse \\ Zentrum für \\ Augenheilkunde \\ Philipps-Universität Marburg \\ Marburg, Germany \\ C.W. Hönemann \\ M.E. Durieux \\ Departments of \\ Pharmacology, \\ Anaesthesiology and \\ Neurosurgery \\ University of Virginia Health \\ Sciences Center \\ Charlottesvile \\ Virginia, USA
}

Gregor W. Nietgen, MD Zentrum für

Augenheilkunde

Philipps-Universität Marburg

Robert-Koch-Strasse 4

35033 Marburg

Germany

Tel: +496421 282600

Fax: +49 6421285678

e-mail:

nietgen@post.med.uni-marburg.de

Supported in part by

National Institutes of Health grant GMS 52387/02 to

M.E.D. G.W.N. was

supported by a grant from the Deutsche

Forschungsgemeinschaft (DFG, Ni 482/1-1). C.W.H. is supported by a grant from the Innovative Medizinische Forschung, Münster, Germany (IMF Hö-1-6-II/98-8)

Received: 14 September 1998

Accepted in revised form: 22 January 1999 
muscarinic and nicotinic receptors, though noted very early, hardly explained their distinct roles in cholinergic signalling. The past decade, however, has seen the molecular cloning of both nicotinic ${ }^{18}$ and muscarinic ${ }^{19}$ acetylcholine receptors in Numa's laboratory, ${ }^{20}$ leading to greatly expanded understanding of these systems. In addition, new research techniques such as patch clamping $^{21}$ and single channel recording ${ }^{22}$ have provided additional insights into the functioning of the cholinergic signalling system.

We now know that, although acetylcholine is the physiological agonist on both nicotinic and muscarinic receptors, they are completely different entities: the first a multi-subunit, ligand-gated ion channel (i.e. an ionotropic receptor), the second a single-subunit, G protein-coupled receptor (i.e. a metabotropic receptor). It appears likely that all muscarinic receptor subtypes have now been cloned, allowing development of specific antibodies, ${ }^{23}$ detailed mapping of tissue distribution, and synthesis of subtype-specific agonists and antagonists (Table 1a). ${ }^{24-26}$ It has become clear that muscarinic signalling plays an important role in multiple locations of the eye, and that ocular cholinergic drugs interfere significantly with this system. This article will focus on the molecular basis of these findings. It will show that the complex distribution of muscarinic receptors in the eye is only a part of many interacting signalling systems, all resulting in the development and maintenance of vision. Following a brief summary of the molecular biology of muscarinic receptors, their distribution and function in the human eye will be described. A description of the clinical implications of these signalling pathways and their interactions in pathological processes will be outlined.

\section{Molecular biology of muscarinic signalling}

The first muscarinic receptor was cloned in $1986 .{ }^{19}$ In the 13 years that have passed, a remarkable amount of information has been gathered about the molecular biology of muscarinic signalling. Not only have (presumably) all subtypes of muscarinic receptors been cloned, but detailed information on their structureactivity relationship is available, which will prove useful in the development of new, highly selective agonist and antagonist drugs.

\section{Muscarinic receptors belong to the G protein-coupled receptor superfamily}

When the DNA encoding the muscarinic receptor had been isolated, it was compared with previously cloned sequences, and its closest relative was found to be the visual pigment rhodopsin. ${ }^{19}$ Although at first this may appear to be an unusual relationship, the sequence similarity relates to the fact that similar intracellular systems transduce the signals generated by these molecules. In both cases, a GTP-binding protein (G protein) forms an intermediate between membrane receptor and intracellular second messenger. More than a thousand receptor types have now been shown to belong to the G protein-coupled receptor (GCR) superfamily, of which the muscarinic receptors form a small but distinguished cluster.

GCRs all show the same molecular signature in their amino acid sequence: most are around 500 amino acids in length and include seven stretches of approximately 20 hydrophobic amino acids each. These domains are thought to form $\alpha$-helices traversing the membrane, leading to the designation of these proteins as seventransmembrane, or, more fancifully, serpentine or heptahelical receptors (Fig. 1).

The $G$ proteins stimulated by receptor activation control a number of intercellular systems. Best described are $G$ proteins stimulating $\left(G_{s}\right)$ and inhibiting $\left(G_{i}\right)$ adenylate cyclase, with corresponding changes in cAMP levels. Phospholipase $C$, activated by $\mathrm{G}_{\mathrm{q}}$ or $\mathrm{G}_{\mathrm{o}}$, generates inositol trisphosphate $\left(\mathrm{IP}_{3}\right.$, which releases $\mathrm{Ca}^{2+}$ from intracellular stores) and diacylglycerol (which activates protein kinase $C$ ). In addition, $G$ proteins can activate ion channels, as in the case of $G_{k}\left(a G_{i}\right.$ subtype), which closes a neuronal potassium channel in response to muscarinic stimulation.

\section{Five muscarinic receptor subtypes have been cloned}

Once the DNA sequence of one muscarinic receptor was known ${ }^{19}$ other subtypes were isolated in rapid succession. Thus far, five muscarinic receptor have been cloned ${ }^{28}$ designated $\mathrm{m} 1, \mathrm{~m} 2, \mathrm{~m} 3, \mathrm{~m} 4$ and $\mathrm{m} 5$. The existence of this many subtypes was surprising, as pharmacological studies suggested initially only two (M1 and M2). Glandular M2 receptors were designated M3. (Names with a capital ' $\mathrm{M}$ ' indicate pharmacologically defined subtypes, whereas those with a small ' $m$ ' indicate clones.) Four pharmacological subtypes have now been defined (M1, M2, M3, M4). ${ }^{29,30}$ This apparent excess of subtypes is typical for GCRs, and presumably allows finer regulation of receptor expression. The five subtypes fall into two groups - the 'odd' (m1, m3, m5) and the 'even' (m2, m4) - based on sequence homology and second messenger signalling. The odd group signals primarily through intracellular $\mathrm{Ca}^{2+}$; the even group through decreases in cAMP production. In the brain or retina, where signalling systems eventually have to transduce their actions through changes in membrane potential, $\mathrm{m} 1$ and $\mathrm{m} 3$ inhibit a $\mathrm{G}$ protein-coupled potassium current $\left(I_{\mathrm{M}}\right)$ and activate a $\mathrm{Ca}^{2 \mathrm{a}}$-activated potassium current $\left(\dot{I}_{\mathrm{K}(\mathrm{ca})}\right)$, a whereas $\mathrm{m} 2$ and $\mathrm{m} 4$ receptors inhibit the $I_{\mathrm{Ca}}$ current through voltageactivated $\mathrm{Ca}^{2+}$ channels (Fig. 2). ${ }^{31}$ Although the clones were numbered in the order they were identified, the $\mathrm{m} 1$ clone happens to show most of the properties of the pharmacological M1 type, and the $\mathrm{m} 2$ clone those of the M2 type; similar correspondences exist with the m3/M3 and $\mathrm{m} 4 / \mathrm{M} 4$ combinations. The presence of the $\mathrm{m} 5$ subtype in several brain regions and in the eye is documented, although its function and pharmacological profile remain to be established. 

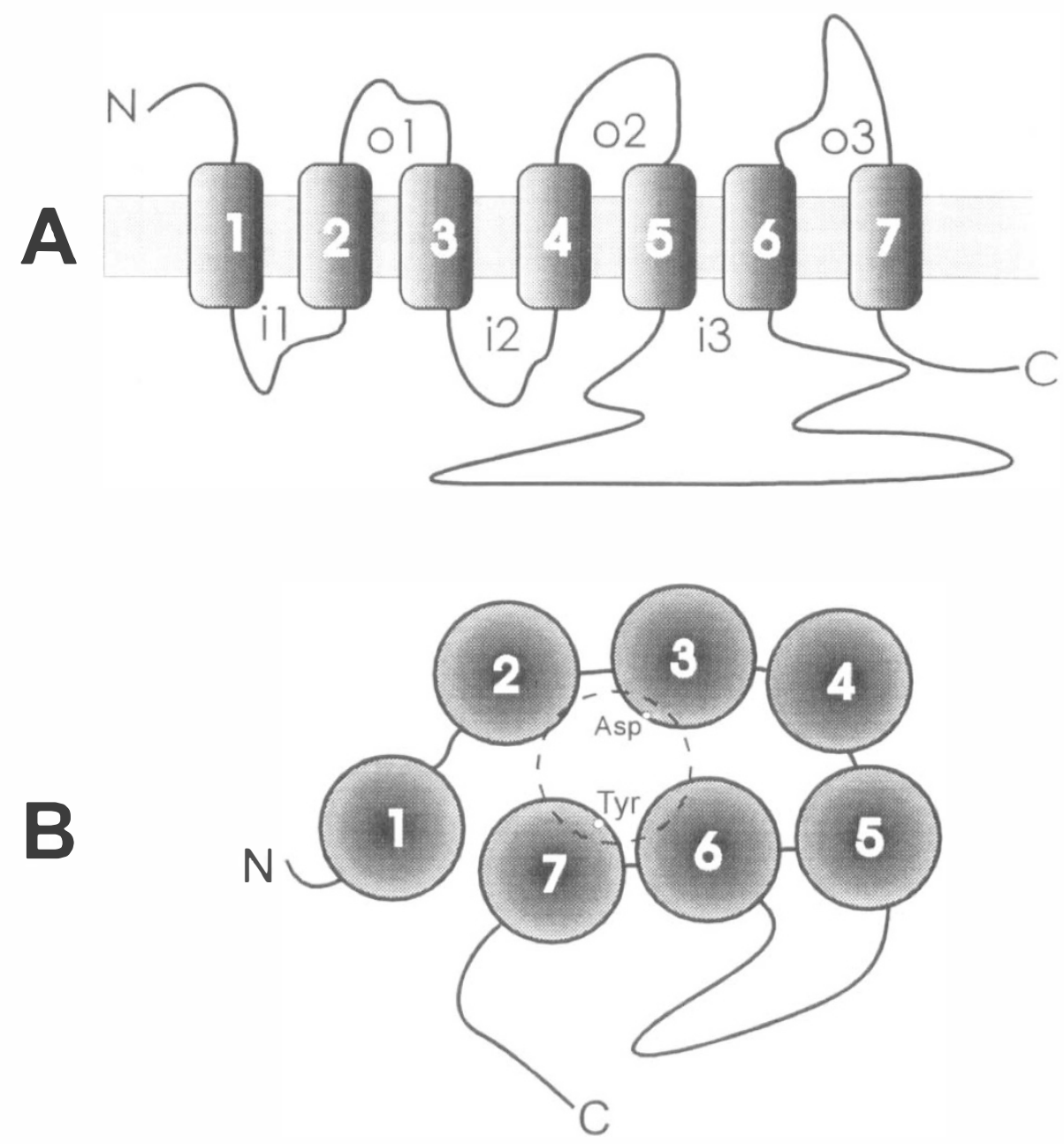

Fig. 1. Model of a muscarinic acetylcholine receptor. (A) Linear model. The whole molecule is approximately 500 amino acids long. Seven hydrophobic stretches of approximately 20 amino acids are present, presumably forming $\alpha$-helices that pass through the cell membrane, thus forming seven transmembrane domains ( $(1-t 7)$. Extracellularly the aminoterminus $(N)$ and three outside loops (01-03) are found; intracellularly there are similarly three loops (i1-i3), and the carboxyterminus (C). (B) Top-down view. Although in (A) the molecule is pictured as a linear complex, the transmembrane domains are thought to be in close proximity, forming an ellipse with a central ligand-binding cavity (indicated by a dashed circle). Asp and Tyr refer to two amino acids important for ligand interaction. G protein binding takes place at the i3 loop and the carboxyterminus. From Durieux. ${ }^{27}$

\section{Muscarinic receptor functions are related to molecular domains}

The cloned muscarinic receptor subtypes and other members of the superfamily have been used to determine the intramolecular sites involved in ligand binding and $G$ protein coupling. As the muscarinic subtypes show 89-98\% amino acid sequence identity in mammalian species, specificity of ligand binding and $G$ protein coupling must depend on relatively small changes in structure. In agreement with their functional grouping, the odd and even receptors show particularly high within-group similarity. There is, however, a remarkable lack of sequence similarity in the third intracellular loop (i3, Fig. 1), with the exception of the first and last 15 to 20 amino acids. Studies of bacteriorhodpsin (a related molecule for which the three-dimensional structure has been established) and adrenergic receptors have demonstrated that ligand binding takes place in a pocket, primarily consisting of the second, third and seventh transmembrane regions $(\mathrm{t} 2, \mathrm{t} 3, \mathrm{t} 7){ }^{32}$ whereas the i3 loop and the carboxyterminus $(\mathrm{C})$ are involved in $\mathrm{G}$ protein binding ${ }^{33}$ and regulation through phosphorylation. ${ }^{34}$ In muscarinic receptors, the $G$ protein binding specificity has been mapped to a remarkably small domain of approximately 20 amino acids in the i3 loop. ${ }^{35}$ As in adrenergic receptors, ${ }^{36}$ agonist binding in muscarinic receptors is initiated by contact with a specific aspartate residue in $\mathrm{t} 3 .^{37}$ Exchange of (part of) $\mathrm{t} 6, \mathrm{i} 3, \mathrm{t} 7$ and $\mathrm{i} 4$ between the $\mathrm{m} 2$ and $\mathrm{m} 3$ subtypes resulted in a change in $\mathrm{G}$ protein coupling and subtype-selective ligand binding. ${ }^{38}$ Mutation studies have shown a series of threonine and tyrosine residues in $\mathrm{t} 3, \mathrm{t} 5, \mathrm{t} 6$ and $\mathrm{t} 7$ that are of importance in agonist, but not antagonist binding, ${ }^{39}$ again demonstrating the role of transmembrane domains for ligand binding. Thus, the functional domains of these receptors are well established and the importance and potential of highly selective ocular drugs for these domains can be foreseen. 


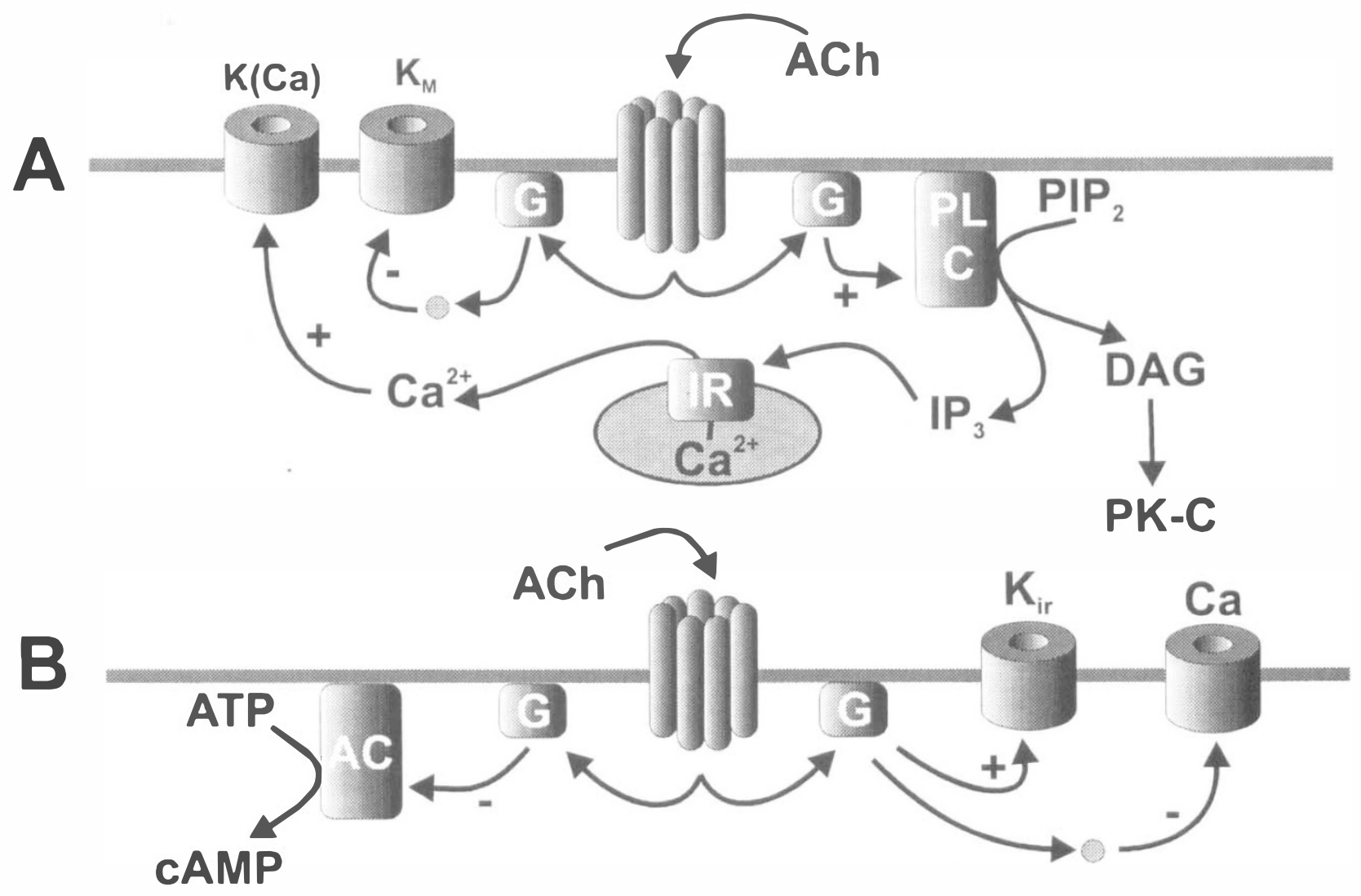

Fig. 2. Intracellular signalling by muscarinic receptors. A composite illustration of the intracellular signalling pathways employed by muscarinic receptors. (A) Signalling through a receptor of the 'odd' group. The receptor (indicated by a stylised 7-transmembrane model) is activated by acetylcholine $(A C h)$ and stimulates two main classes of $G$ protein $(G)$. One class, consisting of members of the $G_{0}$ and $G_{a}$, families, activates phospholipase $C(P L-C)$. This results in the breakdown of phosphatidylinositol bisphosphate $\left(P_{2} P_{2}\right)$ to inositol trisphosphate (IP3) and diacylglycerol $(D A G) . I P_{3}$ acting through its own receptor $(I R)$ releases $\mathrm{Ca}^{2+}$ from internal stores, which can activate Ca-activated $\mathrm{K}$ channels $\left(K_{(C a)}\right)$. However, in neurons, $I_{\mathrm{K}(\mathrm{Ca})}$ is often inhibited by muscarinic stimulation via unclear pathways. DAG activiates protein kinase $C$ (PK-C). The other $G$ protein, presumably $G_{q / 11}$, closes $K$ channels $\left(K_{m}\right)$ in neuronal membranes through an as yet unidentified intermediary. (B) Signalling through a receptor of the 'even' group. Again several $G$ proteins are involved. One, presumably a member of the $G_{i}$ class, inhibits adenylate cyclase (AC) resulting in a decrease in the conversion of ATP to $C A M P$, and thus decreased cAMP levels. Another $G$ protein, probably $G_{0}$, inhibits an $N$-type Ca channel (Ca) through an unidentified intermediary. In cardiac tissue (and possibly in neurons), activation of $G_{k}$ directly opens a $K_{i r}$ channel. Specific types of $G$ proteins have not been indicated in the figure, as most have not been formally identified in studies. Not all cells expressing muscarinic receptors will show all signalling pathways indicated. From Durieux. ${ }^{27}$

\section{Pharmacology of muscarinic signalling}

Until the first cloning of a muscarinic receptor was achieved in 1986, ${ }^{19}$ investigators depended on pharmacological tools, primarily selective antagonists, to define the several subtypes of this receptor family. Unfortunately, none of the known antagonists is completely selective, so that subtypes had to be defined by measuring the binding properties of several compounds. Thus, equilibrium binding studies with pirenzipine initially indicated the existence of two classes of cerebral muscarinic receptors, named M1 and M2. ${ }^{26,40}$ Kinetic studies allowed differentiation of three subtypes ${ }^{41}$ and with the development of novel antagonists this number was expanded to four (M1-M4). ${ }^{42}$ Tables $1 \mathrm{a}$ and $1 \mathrm{~b}$ indicate the relative selectivity of the commonly used muscarinic antagonists, and relate the pharmacologically defined types to the cloned receptor genes. An excellent recent review of this subject is available. ${ }^{24}$ Whereas many useful muscarinic antagonists have been developed, drugs with selective agonist activity are not as widely available. Acetylcholine and most of the classical parasympathomimetic drugs (carbachol, arecoline, muscarinic and pilocarpine) are non-selective. In functional studies several experimental compounds have displayed some selectivity for $\mathrm{M}^{43}$ and $\mathrm{M} 2{ }^{44}$ receptors. However, these substances exhibit a functional selectivity for the receptor subtypes only and show no or only limited selectivity in terms of affinity. ${ }^{45}$ So far even modestly selective agonists for the M3 and M4 subtypes are not available. Overall, since the cloning of the first muscarinic receptor a remarkable amount of information has been gathered about the molecular biology of muscarinic signalling. Not only have the main classes of muscarinic receptor subtypes been cloned, but detailed information on their structure-activity relationship is available, which has already proved useful in the development of new, highly selective agonist and antagonist drugs. 
Table 1a. An overview of differences in selectivity of various muscarinic antagonists ${ }^{\mathrm{a}}$

\begin{tabular}{lccccc}
\hline cDNA: & $\mathrm{m} 1$ & $\mathrm{~m} 2$ & $\mathrm{~m} 3$ & $\mathrm{~m} 4$ & $\mathrm{~m} 5$ \\
Subtype: & $\mathrm{M} 1$ & $\mathrm{M} 2$ & $\mathrm{M} 3$ & $\mathrm{M} 4$ & \\
\hline Pirenzepine & ++ & + & + & ++ & + \\
AFDX 116 & + & ++ & + & + & + \\
Himbacine & + & ++ & + & ++ & + \\
Methroctamine & ++ & ++ & + & ++ & + \\
4-DAMP & + & + & ++ & ++ & ++ \\
pFHHSiD & + & + & ++ & ++ & ++ \\
\hline
\end{tabular}

${ }^{a}$ Based on potencies from functional or radioligand binding experiments on muscarinic receptors.

+ , relatively low affinity; ++ , relatively high affinity. AFDX 116 [11-2[[2-(9-diethylamino)methyl]-1-piperidnl]acetyl]-5,11-dihydro-6H-pyrido[2,3-b][1,4]benzodiazepin]-6-one, 4-DAMP, 4-diphenylacetoxylmethyl piperidine methiodide; $\mathrm{pFHHSiD}$, parafluorohexahydrosiladifenidol.

\section{Intracellular pathways}

As stated earlier, $\mathrm{Ca}^{2+}$ and cAMP are the best-described intracellular second messengers of the 'odd' and 'even' receptor groups, respectively. In the eye, with its primary function of electrical signalling, muscarinic systems also transduce their actions through changes in membrane potential. Several ion conductances, mainly in neuronal cells, have been shown to be affected by muscarinic stimulation, and the effects are most easily classified as depolarising (stimulatory) or hyperpolarising (inhibitory). ${ }^{24,31}$ The best-known depolarising effect is by inhibition of a non-inactivating voltage-gated $\mathrm{K}^{+}$ channel. $\left(I_{\mathrm{K}(\mathrm{m})}\right)$ that clamps the membrane at its resting potential. ${ }^{46}$ Stimulation of (primarily) M1 receptors inhibits this channel, resulting in a neuron more likely to fire when depolarised by other agonists. This effect has been studied in some detail, and has been shown to be mediated through the $\mathrm{G}_{\mathrm{q} / 11} \mathrm{G}$ protein. ${ }^{47}$ A second depolarising influence of muscarinic signalling is through inhibition of a $\mathrm{Ca}^{2+}$-dated $\mathrm{K}^{+}$current $\left(I_{\mathrm{K}(\mathrm{Ca})}\right)$, which normally hyperpolarises the cell when an action potential leads to influx of $\mathrm{Ca}^{2+}$ through voltageactivated $\mathrm{Ca}^{2+}$ channels. ${ }^{48} \mathrm{M} 1$ receptors seem to be the primary subtype involved, which is surprising, because

Table 1b. The selectivity ratios of different muscarinic antagonists ${ }^{a}$

\begin{tabular}{lccc}
\hline & \multicolumn{3}{c}{ Selectivity $^{b}$} \\
\cline { 2 - 4 } Antagonist & M1 vs M2 & M1 vs M3 & M2 vs M3 \\
\hline Atropine & $2.1^{*}$ & $2.6^{*}$ & 1.2 \\
Telenzepine & $26.3^{*}$ & $4.6^{*}$ & $0.17^{*}$ \\
QNX & $4.0^{*}$ & $0.45^{*}$ & $0.11^{*}$ \\
Pirenzepine & $37.2^{*}$ & $11.2^{*}$ & $0.30^{*}$ \\
4-DAMP & $18.6^{*}$ & $1.8^{*}$ & $0.10^{*}$ \\
Procyclidine & $15.8^{*}$ & $4.3^{*}$ & $0.27^{*}$ \\
Dicyclomine & $34.7^{*}$ & $2.6^{*}$ & $0.074^{*}$ \\
AFDX 116 & $0.24^{*}$ & $6.2^{*}$ & $25.6^{*}$ \\
\hline
\end{tabular}

From Doods. $^{29}$

QNX, RS-( \pm )-quinuclidinyl xanthene-9-carboxylate hemioxalate hydrate.

*Significantly different from $1(p<0.05)$.

${ }^{a}$ In in vivo radioligand binding studies of muscarinic binding sites in hippocampus, atrium and submandibular gland.

${ }^{b} \mathrm{M} x$ vs $\mathrm{M} y=\mathrm{K}_{\mathrm{i}(y)} / \mathrm{K}_{\mathrm{i}(x)}$. their stimulation leads to increases in intracellular $\mathrm{Ca}^{2+}$ and therefore activation rather than inhibition of $I_{\mathrm{K}(\mathrm{Ca})}$ would be expected. Such is indeed seen in transfected cells ${ }^{49}$ but it has not been observed in neurons. The mediator involved has not been defined.

Inhibitory effects of muscarinic signalling are found in many neurons, and the best-defined pathway is the muscarinic effect on voltage-activated $\mathrm{Ca}^{2+}$ currents $\left(I_{(\mathrm{Ca})}\right)$. This appears to be mediated by $\mathrm{m} 2$ or $\mathrm{m} 4$ receptors activating $\mathrm{G}_{0}$ proteins. ${ }^{50}$ The $\mathrm{N}$-type $\mathrm{Ca}$ channel involved is sensitive to the Ca-channel blocker $\Omega$-conotoxin GVIA but not to dihydropyridines. Another inhibitory effect of muscarinic signalling, even though only documented in cardiac atrial cells, is the activation of inwardly rectifying $K$ channels $\left(K_{i}\right)$ through M2 stimulation. This is responsible for the cardiac side effects of topically applied anticholinergic ophthalmic drugs, and has been shown to result from direct activity of stimulated $G_{i}$ proteins on the channel. Dimming of vision, especially reported after use of carbachol, ${ }^{51}$ might be a direct effect on retinal muscarinic signalling. A recent review on the subject is available. ${ }^{52}$ Much interest has been generated by findings that the $G$ protein $\beta$-subunit, traditionally considered inactive, appears to play an important role in this effect. ${ }^{53,54}$ Although most data have been obtained in atrial cells, there is evidence that similar pathways exist in retinal ${ }^{14,55}$ and cerebral signal transduction. ${ }^{56}$ Fig. 2 summarises the intracellular pathways involved in muscarinic signalling. This area is the subject of active investigation, and several recent, more extensive reviews exist. ${ }^{24,57,58}$

\section{Conclusions}

The investigations that followed cloning of the muscarinic receptors have provided first insights into the complex action they play in normal physiology and in the diseased eye. Ocular pharmacologically active substances can not be seen as having one receptor subtype at one tissue site within the eye - in the case of muscarinic agents several short-term and long-term effects must be considered. Besides the widely present muscarinic receptors, many classes of other GCRs are present in the eye. Structural studies, as well as determination of interactions with their secondary signalling mechanisms, will serve in the understanding and evaluation of phenomena such as elevated IOP or visual disturbances and alterations induced by various drugs. These findings can not be explained alone by the structural features of these substances and their affinity towards one receptor type. The interaction of muscarinic signalling with other signalling systems and the influence on slow pace growth promotion, smooth muscle activation and fast neuronal signalling are woven together in a complex pattern. Side effects and sometimes surprisingly beneficial observations can therefore be explained when muscarinic agonists and antagonists are used in ophthalmology. In the last 15 years highly selective drugs for certain muscarinic receptor subtypes have been discovered. Their clinical usefulness is in 
many cases still elusive. The understanding of the ocular muscarinic system is therefore of great interest for the clinical ophthalmologist, since the selectivity of today's drugs requires a far more detailed understanding for their optimal application.

\section{Localisation and function of muscarinic receptors in the eye}

Understanding the functional importance of muscarcinic receptor signalling in the eye requires knowledge of the exact localisation of the receptors and subtype composition. The indication that a muscarinic receptor subtype is expressed in a certain part of the eye is taken as putative evidence that a functional role for this certain subtype exists. Not only anatomical curiosity, but also the search for reliable drugs for glaucoma and other disorders (e.g. myopia) drive efforts in mapping the quantity and types of ocular muscarinic receptors. From the observation that cholinergic drugs have effects on miosis, refraction and visual acuity it was deduced that muscarinic signalling must play a role in these processes. In addition, the development of new and more specific agonists and antagonists is of special interest for the treatment and management of ocular hypertension. Side effects developing from the long-term administration of these substances make it desirable to develop, if possible, drugs that do not have many of the undesired effects of many anticholinergics currently in use.

Separate from the functions of the mechanical apparatus are those of retinal signal transduction. Neurochemical processes important to signal transduction of visual information are believed to be modulated by a wide variety of expressed receptors in various defined structures of the retina and optic nerve. These may require more prolonged efforts in mapping and characterisation than the rest of the optic system. For the detection of receptors various methods exist, each with a variety of benefits and disadvantages, that have to be considered in their interpretation. Three different methods of investigation are highlighted here: binding studies, the use of monoclonal antibodies and the detection of mRNA encoding the specific receptor subtype. Using these techniques, a reasonably complete picture of ocular muscarinic receptor distribution can be drawn (Table 2).

Binding studies have historically been the most prominent type of investigations of muscarinic receptors. Several specific muscarinic agonists and antagonists exist, with which the distribution of muscarinic receptors in the eye has been defined. The major disadvantage of the method is that the specificity of these substances is only modest in most cases. Substances used to identify muscarinic receptor subtypes (M1, M2) do not necessarily bind with similar affinity to the cloned receptor subtypes $(\mathrm{m} 1, \mathrm{~m} 2) .{ }^{73}$ However, careful comparison of binding studies using several antagonists can reveal consistent patterns of receptor distribution. An overview of the most commonly used antagonists used in binding studies is given in Tables $1 \mathrm{a}$, together with their specificity on the different muscarinic receptor subtypes and their binding ratios between the M1 to M3 subtypes (Table 1b). Muscarinic receptor research has been hindered by the lack of antagonists with high affinity for one receptor subtype coupled with very low affinity for the other four receptor types. This results in the necessity to define a particular subtype with dissociation constants for a range of selective antagonists. $^{24}$

Complementary nucleic acid sequences that are able to hybridise with parts of muscarinic receptor mRNA, either in Northern blots from tissues or directly in tissue sections, as in situ hybridisation, have proved another powerful tool in receptor mapping in the human eye. The presence of mRNA, when found in in situ tissue hybridisations, is usually a very strong indicator for the expression of the receptor molecule itself. Since many studies have been performed on isolated cell cultures from eye tissue, especially ciliary cells, ${ }^{60}$ divergent results were reported regarding the expression of receptor subtypes in these tissues. This is not surprising, since cultured cells are isolated and are devoid of the interactive intercellular communication processes regulating receptor expression. Other reasons for, in particular, muscular diversity of muscarinic receptor expression are that the cell line derived from ocular tissue can have differential activation capacities for expression and that different rates of transcription exist. This has been described within the family of muscarinic receptors previously. ${ }^{74}$ Therefore, results from cultured tissues are not always comparable with the status in vivo, even if more elegant examination methods in cultured tissues exist.

Monoclonal antibodies against various muscarinic subtypes have been introduced and their use in localisation studies will eventually give the most reliable insight into receptor expression. Most antibodies have been raised against peptide sequences of the third intracellular loop (i3) of each receptor, since this area has the least sequence homology among subtypes, ${ }^{23}$ or against peptides of the carboxy end (e.g. of the m3 sequence) ${ }^{75}$ Subtypes have been described in various organs and parts of the central nervous system but no subtype-specific investigations with monoclonal antibodies in the human eye have yet been performed. This leaves a wide gap in the knowledge we have so far achieved from binding and expression studies. The necessity actually to identify the expressed receptor subtypes is crucial, since their assignment to functional effects has already been studied with selective muscarinic drugs. Resolution problems, combined with low sensitivity, are presumably the main obstacles that have hindered antibody investigations in ocular tissues. Additionally, the absence of a definitive classification of subtypes might not be surprising, since many studies experience difficulties in conclusively designating a specific subtype of receptor with in situ hybridisation, antibodies and functional pharmacological studies. 
Table 2. The distribution of muscarinic receptor subtypes in distinct anatomical spaces of the human eye and in that of other species

\begin{tabular}{|c|c|c|c|c|}
\hline Tissue & $\begin{array}{l}\text { Direct protein } \\
\text { detection }\end{array}$ & $\begin{array}{l}\mathrm{m} 1-\mathrm{m} 5 \mathrm{mRNA} \\
\text { in situ hybridisation }\end{array}$ & $\begin{array}{l}\text { m1-m5 mRNA } \\
\text { northern blot }\end{array}$ & $\begin{array}{l}\text { M1-M4 radioligand } \\
\text { binding }\end{array}$ \\
\hline $\begin{array}{l}\text { Cornea } \\
\text { Epithelium }\end{array}$ & $\begin{array}{l}\mathrm{m} 3^{\mathrm{m}} \\
\mathrm{m} 4^{\mathrm{m}} \\
\mathrm{m} 5^{\mathrm{m}} \\
\mathrm{m} 1 \text { or } \mathrm{m} 2^{\mathrm{m}}\end{array}$ & $\begin{array}{l}\mathrm{m} 3+^{\mathrm{a}} \\
\mathrm{m} 3+^{\mathrm{a}}\end{array}$ & & $\begin{array}{l}\text { QNB binding: } \\
\text { subtypes not specified }{ }^{\mathrm{n}, \mathrm{o}}\end{array}$ \\
\hline Endothelium & $\begin{array}{l}\mathrm{m} 3^{\mathrm{m}} \\
\mathrm{m} 4^{\mathrm{m}} \\
\mathrm{m} 5^{\mathrm{m}}\end{array}$ & & & \\
\hline $\begin{array}{l}\text { Lens } \\
\text { Anterior epithelium }\end{array}$ & & $\mathrm{m} 3+^{\mathrm{a}}$ & & \\
\hline $\begin{array}{l}\text { Trabecular meshwork } \\
\text { Ciliary non-pigmented } \\
\text { epithelium/process }\end{array}$ & & $\begin{array}{l}\mathrm{m} 3+^{\mathrm{a}} \\
\mathrm{m} 3+^{\mathrm{a}}\end{array}$ & $\begin{array}{l}\mathrm{m} 2+^{\mathrm{f}} \\
\mathrm{m} 3+++^{\mathrm{f}} \\
\mathrm{m} 4+^{\mathrm{f}}\end{array}$ & $\begin{array}{l}\mathrm{M} 1+++^{\mathrm{k}} \\
\mathrm{M} 1++^{\mathrm{c}} \\
\mathrm{M} 2++^{\mathrm{c}, \mathrm{k}} \\
\mathrm{M} 3++^{\mathrm{j}} \\
\mathrm{M} 3+++^{1}\end{array}$ \\
\hline $\begin{array}{l}\text { Cililary muscle } \\
\text { Whole muscle }\end{array}$ & $\begin{array}{l}\mathrm{m} 3++^{\mathrm{p}} \\
\mathrm{m} 1+^{\mathrm{P}} \\
\mathrm{m} 2+^{\mathrm{P}} \\
\mathrm{m} 4+^{\mathrm{P}} \\
\mathrm{m} 5+^{\mathrm{P}}\end{array}$ & $\mathrm{m} 3++^{\mathrm{a}}$ & $\mathrm{m} 3+^{\mathrm{a}}$ & $\begin{array}{l}\mathrm{M} 2+^{\mathrm{c}} \\
\mathrm{M} 3+^{\mathrm{a}, \mathrm{d}, \mathrm{e}}\end{array}$ \\
\hline Longitudinal & & $\begin{array}{l}\mathrm{m} 2+^{\mathrm{b}} \\
\mathrm{m} 3+^{\mathrm{b}} \\
\mathrm{m} 5++^{\mathrm{b}}\end{array}$ & $\begin{array}{l}\mathrm{m} 1+{ }^{\mathrm{b}} \\
\mathrm{m} 2+{ }^{\mathrm{b}} \\
\mathrm{m} 3+{ }^{\mathrm{b}} \\
\mathrm{m} 4+{ }^{\mathrm{b}} \\
\mathrm{m} 5+{ }^{\mathrm{b}}\end{array}$ & $\begin{array}{l}\mathrm{M} 1++^{\mathrm{c}} \\
\mathrm{M} 2+++^{\mathrm{c}}\end{array}$ \\
\hline Circular & & $\begin{array}{l}\mathrm{m} 2++^{\mathrm{b}} \\
\mathrm{m} 3++^{\mathrm{b}} \\
\mathrm{m} 5+^{\mathrm{b}}\end{array}$ & $\begin{array}{l}\mathrm{m} 1+^{\mathrm{b}} \\
\mathrm{m} 2+^{\mathrm{b}} \\
\mathrm{m} 3+^{\mathrm{b}} \\
\mathrm{m} 4+^{\mathrm{b}} \\
\mathrm{m} 5+^{\mathrm{b}}\end{array}$ & $\begin{array}{l}\mathrm{M} 1++^{\mathrm{c}} \\
\mathrm{M} 2+^{\mathrm{c}}\end{array}$ \\
\hline Iris & & $\mathrm{m} 3++^{\mathrm{a}}$ & $\mathrm{m} 3+^{\mathrm{a}}$ & $\begin{array}{l}\mathrm{M} 2++^{\mathrm{c}} \\
\mathrm{M} 3++^{\mathrm{c}}\end{array}$ \\
\hline Sphincter & & & $\begin{array}{l}\mathrm{m} 2+^{\mathrm{f}} \\
\mathrm{m} 3+++^{\mathrm{f}} \\
\mathrm{m} 4+^{\mathrm{f}}\end{array}$ & $\begin{array}{l}\text { M3 }+++^{a, d}{ }^{f} \\
\text { M1 }++^{c}\end{array}$ \\
\hline Epithelium & & & & $\begin{array}{l}\mathrm{M} 3+^{\mathrm{a}} \\
\mathrm{M} 1++^{\mathrm{c}}\end{array}$ \\
\hline Retina & $\mathrm{m} 1$ to $\mathrm{m} 5^{\mathrm{h}}$ & & & $\begin{array}{l}\mathrm{M} 1++^{\mathrm{c}} \\
\mathrm{M} 2+^{\mathrm{c}, \mathrm{g}, \mathrm{i}} \\
\mathrm{M} 3+^{\mathrm{a}}\end{array}$ \\
\hline Sclera & & & & $\mathrm{M} 1++^{\mathrm{P}}$ \\
\hline
\end{tabular}

The comparison of different kinds of investigative tools (radioligand binding, mRNA detection and direct protein detection with monoclonal antibodies) shows a distribution pattern at some anatomical sites. When comparisons of levels of expression were made in a study these are represented as + for present to +++ for predominant.

References: $a ; *, 59 ; b^{*}, 60 ; c^{*}, 61 ; d^{*}, 62 ; e^{*}, 63 ; f, 64 ; g, 65 ; h, 66 ; i, 67 ; j, 68 ; k, 69 ; 1,70 ; m, 15 ; n, 16 ; 0,71 ; p, 72$. An asterisk indicates investigations made in human tissue.

QNB, quinuclidinyl benzylate.

\section{Muscarinic signalling in the retina}

Autoradiographic binding sites for muscarinic agents in the retina have been difficult to allocate, since the spatial resolution of this technique was not satisfactory. ${ }^{76}$

Higher-resolution studies and more advanced emulsion techniques, however, revealed the existence of M1 and $\mathrm{M} 2$ receptors in rat, human and monkey, ${ }^{77-79}$ as well as in calf, ${ }^{80}$ avian $^{14,81}$ fish $^{82}$ and rabbit $^{83}$ retina, where they are mainly found in the inner plexiform layer from early stages onwards in the developing eye. These findings impressively demonstrate the crucial role of muscarinic signalling in embryonic development and in the adult eye, since multiple patterns of expression appear to guide the layout of retinal structures and later participate in visual function throughout ocular growth. A number of possible mechanisms for the development generation of neuronal networks have been postulated on the basis of changing receptor densities and appearances in the embryogenesis of the eye. ${ }^{84}$ The development of retinal structures appears to be greatly influenced by the expression of muscarinic receptors. ${ }^{85}$ In different stages 
of embryological and postnatal development, the subtypes, number and distribution of the muscarinic receptor proteins change during retinal synaptogenesis. ${ }^{66}$ In embyronic maturation, muscarinic signalling seems to influence formation of retinal structures primarily through intracellular $\mathrm{Ca}^{2+}$ release, ${ }^{14,86,87}$ and muscarinic signalling is predominantly responsible for the incurvation of the early embyronic neural retina. ${ }^{17,88}$ Since precursors of ganglion and amacrine cells possess muscarinic receptors, ${ }^{81,89}$ the concomitant emergence of different functional cholinergic receptor subtypes with differentiation in vivo suggests that acetylcholine plays diverse and temporarily regulating roles in the developing retina. ${ }^{87,90}$

The subtype composition of muscarinic receptors in the retina can not be interpreted at present. 4-DAMP labelling revealed binding to muscarinic receptors in the retina and blocking of $\mathrm{M} 1$ receptors with pirenzepine presumably indicated the concomitant presence of M3 receptors in human retina as well..$^{59}$ Stimulation experiments for GTPase activity revealed that the major site for muscarinic stimulation in bovine retinal membranes is pharmacologically similar to $\mathrm{M} 2$ receptor sites $^{67}$ and in the rat retina phosphoinositide hydrolysis and adenylate cyclase inhibition were mainly found to be induced by M1 subtypes. ${ }^{91}$ However, the accompanying presence of molecularly defined $\mathrm{m} 4$ and $\mathrm{m} 5$ receptors can not be excluded from these findings, since affinities of the employed antagonist for these receptor subtypes exist. The $\mathrm{m} 4$ and $\mathrm{m} 5$ clones in the retina can not be defined at present with specific antagonists, so that care is needed in interpreting binding studies and their true correlation with the molecular subtypes. Investigations with monoclonal antibodies or mRNA hybridisations of these subtypes, except in the developing ferret retina, ${ }^{66}$ are not available and will ultimately determine exact locations of these receptor subtypes. However, the role of cholinergic neurotransmission by muscarinic as well as nicotinic receptors is evident, though investigations of these complex patterns of signal transduction are yet to be performed. Physiological evidence suggests that muscarinic binding sites in the inner plexiform layer are associated with amacrine and/or ganglion cells, ${ }^{92,93}$ although from other studies it appears that association with bipolar and horizontal cells is also possible. ${ }^{79}$ Markers for cholinergic synapases are concentrated in the inner plexiform layer were acetylcholine is possibly being released by discrete populations of amacrine, displaced amacrine and inner bipolar cells. ${ }^{93,94}$

Functional correlations regarding the transmission of chromatic information, patterns or even whole visual images have not been defined but the presence of multiple receptor populations and their interactions are documented. ${ }^{79}$ The release of acetylcholine from displaced amacrine cells under the influence of light in rabbits has been well documented ${ }^{95}$ and effects of acetylcholine from these cells on the inner plexiform layer appear to play a role in subsequent signal transduction. ${ }^{96,97}$

\section{Ciliary muscle function is regulated by muscarinic receptors}

A second important and extremely well investigated site of muscarinic signalling in the human eye is the ciliary muscle. ${ }^{98}$ The ciliary body and the trabecular meshwork have been in the initial focus of interest regarding muscarinic signalling, since they are crucial for accommodation and aqueous outflow. It has become evident that in ciliary muscle a diversification of receptor distribution exists. ${ }^{99,100}$ The general presence of muscarinic receptors in the ciliary muscle complex was soon established ${ }^{70,101,102}$ but further identification of the receptor subtypes seemed desirable for the explanation of accommodative and aqueous flow mechanisms. In the hope of finding an agonist of muscarinic signalling for the control of IOP, precise mappings of muscarinic subtypes through binding studies and molecular genetics have been undertaken. ${ }^{100}$ The most prominent effect of muscarinic drugs in the eye due to constriction of the ciliary muscle is miosis, associated with accommodation and an increased outflow of aqueous humour. ${ }^{13,103,104}$ Since the ciliary muscle can be mechanically divided into a circular portion of muscle fibres responsible for changes in accommodation and a longitudinal portion mainly responsible for changes in outflow facility, the question was soon asked whether differences in receptor distribution were responsible for this distinctive behaviour. Oxotremorine, a selective M2 agonist, binds specifically to sites on the longitudinal ciliary muscle. ${ }^{61}$ The circular muscles, responsible for accommodation, have lower affinity, and it seems possible to influence outflow only by activating especially the longitudinal ciliary muscle fibre subtype. Similar findings were reported with the muscarinic agonist aceclidine when compared with the non-selective pilocarpine. ${ }^{105-107}$ Dose-effect relationships for intracamerally applied doses of aceclidine to determine total outflow and accommodative amplitude were carried out in cynomolgus monkey eyes in vivo. The results showed a significantly stronger effect of aceclidine on outflow than on accommodation, giving further evidence for a dissociation between the accommodative and outflow facility functions of the ciliary muscle based on muscarinic activity. ${ }^{108}$ Additionally, in the monkey eye longitudinal ciliary muscle fibres differ ultrastructurally and histochemically from fibres in other regions of the ciliary muscle, ${ }^{109}$ providing further evidence for a specialised task in regulating humour dynamics. As previously mentioned, aceclidine, a cholinomimetic, has been used therapeutically for IOP reduction in glaucoma ${ }^{110}$ and is known to have far less effect on accommodation than pilocarpine. ${ }^{111-113}$ A specific receptor subtype for aceclidine action was postulated with a site predominantly on the longitudinal portion of ciliary muscles. ${ }^{13,105,108}$ This led in the ensuing period to an intense investigation of muscarinic receptor populations in ciliary muscle tissue and in the trabecular meshwork. Additionally a number of functional studies were added to determine precise mechanisms of 
muscarinic receptor interplay. ${ }^{13,106,114-117}$ Radioligand binding studies revealed that oxotremorine as a weak M2 agonist binds selectively to the longitudinal fibres of the ciliary process whereas no binding was seen in the iris or ciliary epithelium. These results suggest that oxotremorine, by binding selectively to receptors on the longitudinal ciliary muscle and inducing its contraction, may modulate outflow facility independently from accommodation and miosis via the M2 subtype. ${ }^{61}$ When bovine iris and whole ciliary body were investigated regarding expression of muscarinic subtypes, the ratio of $\mathrm{m} 3$ to $\mathrm{m} 4$ subtype mRNA expression was found to be $13: 1$. Absence of $m 1 \mathrm{mRNA}$ in the ciliary process and the iris sphincter was noted, but small quantities of $\mathrm{m} 4$ mRNA were expressed in the ciliary process. ${ }^{64}$ It is evident that the predominant muscarinic receptor in ciliary structures is the m3/M3 subtype, both in human ciliary epithelium ${ }^{3}$ and ciliary muscle ${ }^{59,60,118}$ as well as in other species. ${ }^{119,120}$

The complex innervation features of the ciliary muscle, however, make a solitary responsibility of muscarinic receptors for the distinction between outflow and accommodation improbable. ${ }^{121,122}$ Since the ciliary muscle, like the iris smooth muscle, is innervated by nerves of the sympathetic, parasympathetic and sensory nervous system, activation or blockade of prejunctional receptors may have an additional influence on ciliary muscle tone since not only postjunctional muscarinic effects are responsible for ciliary muscle tone. Therefore, it can be difficult to predict what overall effect an agonist has, because it may differentially affect various parts of the nervous system simultaneously. Sympathetic nerve terminals in the anterior uvea, for example, contain prejunctional muscarinic receptors that, upon activation by agonists, inhibit the neural release of noradrenaline. When the prejunctional effects of muscarinic agents on evoked secretion of noradrenaline in iris-ciliary body segments were investigated, the M2 type was found to be the primary subtype present, the M1 and M3 subtypes playing a minor role. ${ }^{123}$

When mRNA expression studies in native and cultured tissue from the human eye were performed a clearer picture evolved: human ciliary muscle definitely expresses the mRNA of subtypes $\mathrm{m} 2, \mathrm{~m} 3$ and $\mathrm{m} 5$ and may also express the mRNA of $\mathrm{m} 1$ and $\mathrm{m} 4$. Differences in expression level of the $\mathrm{m} 2, \mathrm{~m} 3$ and $\mathrm{m} 5$ subtypes were observed between the circular and longitudinal portions of the ciliary muscle, but quite pronounced expression of all three subtypes of muscarinic receptors by both portions shows that a differential distribution probably is not solely responsible for the dissociation between outflow facility and accommodation that is seen under certain conditions. ${ }^{60}$ The employment of subtype-specific antibodies will be the ultimate confirmation of these findings, since recent experiments with primates indicate that muscarinic receptor subtype distribution plays a minor role in facilitating outflow and lowering IOP. ${ }^{105}$

Echothiophate-induced modulation of functional cholinergic sensitivity in the parasympathetically innervated, in contrast to denervated, ciliary muscle has been shown to occur by a muscarinic-receptor-mediated process. ${ }^{114,115,124}$ Therefore, it is probable that muscarinic receptors also play a role in mediating the inhibitory effects of parasympathetic nerve stimulation or cholinomimetic drugs on ocular sympathetic neurotransmission, indicating their crucial role in ciliary muscle cholinergic sensitivity. The trabecular meshwork, even though not a part of the ciliary muscle, is additionally involved in outflow regulation, as biomechanical studies in the monkey have shown. Here it was noted that pathophysiological changes in the outflow apparatus induced by echothiopate are in part mediated by anterior segment muscarinic receptors as well as mechanical factors. ${ }^{125}$ The M3 subtype appears to be predominant in cultured ${ }^{126}$ and native ${ }^{59}$ human trabecular meshwork cells. However, it has to be mentioned that here again muscarinic signalling is only partially responsible for drug effects. Functional muscarinic, $\alpha$-adrenergic and $\beta$-adrenergic receptors in bovine trabecular meshwork and ciliary muscle are differentially modulated by various drugs: cholinergic and $\alpha$-adrenergic agonists induce contraction, whereas $\beta$ agonists induce relaxation. ${ }^{120}$

\section{Muscarinic receptors of the ciliary epithelium}

In addition to fluid transport through capillary walls, about $95 \%$ of aqueous humour is formed by a secretory process of the cells of the ciliary epithelium. This secretory mechanism and its regulation are only faintly understood and it has become one of the key targets for regulation by endogenous mediators and anti-glaucoma drugs. Multiple methodologies and conflicting results, depending on the animal species used, have created a complex picture of the role of muscarinic receptors in this process. ${ }^{127}$ When the effects of cholinergic agents on vasoactive intestinal peptide(VIP)-stimulated cAMP accumulation were investigated in the rabbit ciliary epithelium, an inhibition of stimulation was found, indicating that the cholinergic system - via muscarinic receptor stimulation and subsequent inhibition of the ciliary epithelial adenylate cyclase - interferes with humour formation. ${ }^{128}$ It remains open as to the biological significance of muscarinic receptors in regulating ciliary epithelial transport, and what their contributions are to intraocular responses to cholinergic drugs. Functional studies with subtype-specific agonists and mapping of the various subtypes are scarce. In human nonpigmented ciliary epithelium the carbachol-specific stimulation of inositol phosphates was significantly inhibited by 4-DAMP (M3 antagonist), showing a distinguishable predominance of $\mathrm{M} 3$ receptor subtypes, with a large variety of other receptors triggered by neurotransmitters and neuropeptides. ${ }^{70}$ In the rabbit non-pigmented epithelium a predominance of muscarinic receptors is seen, in contrast to the pigmented part, which contains mainly $\alpha 1$-adrenergic receptors. ${ }^{128}$ These muscarinic receptors appear to signal via the turnover of membrane phosphoinoitides, generating the second messengers diacylglycerol and $\mathrm{IP}_{3}{ }^{129}$ and via the 
inhibition of adenylate cyclase, ${ }^{128}$ suggesting that at least two of the five molecularly defined subtypes are present in the ciliary epithelium: one of the 'odd' group (m3/M3 as shown ${ }^{59}$ ) and one of the 'even' group, the identity of which remains unknown. The crosstalk between cAMPand $\mathrm{IP}_{3}$-dependent $\mathrm{Ca}^{2+}$ generation has been summarised in a recent review and provides clearer insight into the complicated patterns of signal transduction in the human eye. ${ }^{4}$ The physiological significance of muscarinic receptors in the ciliary epithelium, however, remains to be established. Complex interference with or modulation of ciliary epithelial muscarinic receptors by other hormones,

neurotransmitters and ocular hypotensive drugs makes the muscarinic system a promising target for the development of IOP-lowering substances, ${ }^{130,131}$ and current data support the strong involvement of muscarinic cholinergic receptors in IOP regulation. ${ }^{3,70,132}$

\section{Muscarinic receptors influence iris sphincter function}

The characteristics of muscarinic receptors mediating relaxation and/or contraction have been intensely investigated since the iris is an ideal model for innervation from the sympathetic, parasympathetic and sensory nervous systems. ${ }^{121}$ It is in addition one of the few smooth muscle organs which can be parasympathetically denervated, ${ }^{133}$ making it generally an interesting model for interaction studies of pre- and postjunctional receptors, not only of the muscarinic type, whose general, non-subtype-specific presence in the iris has been documented in a variety of species. ${ }^{134-139}$

The first report of putative muscarinic receptors by non-subtype-specific binding studies in the human iris soon followed, showing high densities of muscarinic receptors in the iris sphincter muscle and lower ones in the dilator muscle, matching with the well-known nonspecific pharmacology of atropine ${ }^{2,140}$ or carbachol. ${ }^{141,142}$ In the rabbit iris sphincter, however, pilocarpine is known as a very weak partial agonist and also behaves as an antagonist, ${ }^{134}$ which was explained by the

combination of a small number of spare receptors and a threshold phenomenon. ${ }^{143}$ Indeed, it was shown that pilocarpine causes miosis in vivo by indirectly decreasing the iris dilator tone via prejunctional inhibition of noradrenaline release in the dilator. ${ }^{144}$ An atypical muscarinic receptor subtype exists in the rabbit iris, ${ }^{145}$ different from the pharmacologically and molecularly defined subtypes, and has accounted for these differences, which were at first attributed to the presence of M3 receptors. ${ }^{146,147}$ The postjunctional M3 receptor subtype appears to be mostly prevalent in guinea pig, ${ }^{148}$ bovine $^{64}$ and human ${ }^{123}$ iris sphincter and rat dilator muscle. ${ }^{149-151}$ Functionally this makes sense, since electrically evoked release of noradrenaline in human iris preparations revealed that prejunctional muscarinic receptors in the human iris-ciliary body correspond to the M2 subtype mediating the inhibitory effects of parasympathetic nerve stimulation or cholinomimetic drugs on ocular sympathetic neurotransmission, whereas the postjunctional M3 subtype is responsible for contraction of the sphincter muscle in humans ${ }^{123,148}$ and in rats. ${ }^{150}$ When the potencies of several muscarinic receptor antagonists in blocking either the autoinhibition of acetylcholine release or the muscarcinic contraction of the sphincter muscle upon acetylcholine release were investigated in the guinea-pig iris, no involvement of the M1 receptor was noted. The results were consistent with the idea of M2 receptors mediating autoinhibition of acetylcholine release and M3-like receptors inducing the contraction of the sphincter muscle in guinea pigs, ${ }_{1}^{148,152}$ in contrast with $\mathrm{M} 2$-mediated $\mathrm{IP}_{3}$ accumulation and subsequent contraction of the sphincter smooth muscle of the rabbit iris. ${ }^{153,154}$

Binding studies of the specific M2 agonist oxotremorine revealed that no M2 subtypes are present in the human iris muscle, in contrast to specific binding of M1 and M3 antagonists. ${ }^{59}$ These findings are supported by the presence of $\mathrm{m} 3$ muscarinic receptor subtype mRNA in native ${ }^{61}$ and cultured ${ }^{155}$ human iris. Investigations in dogs and cats show that the signalling pathways by M3 receptors in the iris smooth muscle involves both intracellular and extracellular $\mathrm{Ca}^{2+}$ mobilisation and subsequent stimulation of cAMP production, and that $\mathrm{M} 3$ receptors are coupled to the activation of both phospholipase $C$ and adenylate cyclase. ${ }^{156,157}$ Contraction of the iris sphincter smooth muscle in rabbits in contrast seems to be primarily mediated by $\mathrm{IP}_{3}$ only. ${ }^{158}$

In conclusion, the understanding of the overall complex nature of muscarinic receptor distribution on various prejunctional and postjunctional sites in the iris is complicated by investigations in different species and inhomogeneous results. Not all species appear to have a similar receptor interplay, making the search for a valid animal model for drug screening problematic. The direct determination of subtypes in humans has been undertaken with radioligand studies; however, their known limitations should be borne in mind.

Investigations of mRNA content or direct protein assays with subtype-specific monoclonal antibodies have revealed that in the human iris sphincter the predominant subtype, as stated before, is the m3 type accounting for $60-75 \%$ of the muscarinic receptors. Lower levels of between $5 \%$ and $10 \%$ were recently found for the $\mathrm{m} 1, \mathrm{~m} 2, \mathrm{~m} 4$ and even the $\mathrm{m} 5$ subtype. ${ }^{100}$

\section{Presence of muscarinic receptors in the cornea}

Among the various mammalian tissues that have been studied for acetylcholine content, the corneal epithelium contains the highest concentrations. ${ }^{159,160}$ Even though corneal epithelium is rich in nerve endings, the enormous concentration of acetylcholine in these cells is not in accordance with the level usually found in junctional tissues where it serves as a neurotransmitter. Suggested functions of acetylcholine might involve regulation of water and ion transport into corneal epithelium. ${ }^{160}$ Denervation of corneal epithelium has led to a $87-100 \%$ reduction in corneal acetylcholine and is 
associated with mitotic (growth) inhibition, suggesting a reparative function of muscarinic receptors in the corneal epithelium. ${ }^{161,162}$ Initial investigations regarding muscarinic receptors showed a lack of binding in rabbit broken cornea preparations, ${ }^{138}$ in contrast with other studies which showed the presence of muscarinic receptors in cultured rabbit corneal cells by QNB binding. ${ }^{71}$ Today the wide presence of muscarinic receptor subtypes in corneal tissues has been documented and a picture of their multiple functions is evolving. Considering that every contact of the cornea with an extraocular object causes a destruction of sensitive corneal epithelium two physiological roles may explain the extensive amount of acetylcholine: first the sensory transmission of the damaging cause and secondly the induction of repair mechanisms, via muscarinic signalling, of an easily damaged thin epithelial layer.

Following these thoughts, a cGMP-mediated stimulatory role of cholinergic receptors in corneal epithelial growth regulation established that activated muscarinic receptors in the cornea are a main signalling step in this procedure. ${ }^{16,163,164}$ After the presence of $\beta$-adrenergic, prostaglandin $E_{1}$ and muscarinic receptors in cultured corneal epithelial cells of the rabbit was established, ${ }^{71}$ the interplay between these receptors was investigated. Hereby it was found that the intercellular cAMP/cGMP ratio was essential for epithelial proliferation and regrowth. The activation of prostaglandin and $\beta$-adrenergic receptors increased cAMP, inhibited regrowth and increased basement membrane production after initial injury to the corneal epithelium. Activation of muscarinic receptors led to increased cGMP-mediated regrowth of the corneal epithelium. The receptor site remained ambiguous and it was assumed that parts of the receptor protein are localised inside the cell, possibly inside the nucleus itself. $^{165}$ Recent investigations in highly purified nuclei of rabbit epithelial and endothelial cell lines have indeed demonstrated the presense of muscarinic receptors inside the nucleus. ${ }^{15}$ Additional whole protein investigations of the molecular subtypes revealed that $\mathrm{m} 3, \mathrm{~m} 4$ and $\mathrm{m} 5$ receptors are present in epithelial and endothelial cells and that $\mathrm{m} 1$ and $\mathrm{m} 2$ receptors are present in epithelial cells only. The majority of these receptors are attached to membranes; the m5 subtype, however, seems likely to regulate nuclear functions, along with an uncharacterised $47 \mathrm{kDa}$ receptor-like protein. This is particularly interesting since the functional role of $\mathrm{m} 5$ is the least understood of all the subtypes. ${ }^{15}$ The intranuclear presence of muscarinic receptors in corneal epithelial and endothelial cells (and other cell types as well) suggests the existence of a functional, possibly G-protein-dependent, nuclear signalling system, induced by muscarinic acetylcholine receptor (or related receptor-like) proteins in response to intracellular acetylcholine, employing pathways specific for intranuclear signalling. ${ }^{166-169}$

\section{Lenticular sites of muscarinic signalling}

The lens, despite its lack of innervation and the fact it is an organ of entirely epithelial origin, has high levels of acetylcholinesterase activity. ${ }^{170}$ Initially this activity was thought to be a defensive mechanism based on the high concentrations of acetylcholine generated by such nearby sources as the iris and the ciliary apparatus. ${ }^{171}$ But soon the functional role of acetylcholine emerged and, interestingly, interference with acetylcholine homeostasis in the lens has been shown to have a remarkable effect on its clarity. A well-known side effect of anticholinergic drugs is their ability to induce cataract in humans, ${ }^{172}$ in in vitro experiments ${ }^{170,173}$ and in monkeys. ${ }^{174}$ In isolated epithelial cell preparations of humans, acetylcholine induced intracellular release of calcium from endoplasmic reticulum in these cells. This signalling pattern goes together with an activation of $\mathrm{m} 1, \mathrm{~m} 3$ or $\mathrm{m} 5$ receptors on the cell surface. Indeed, further electrophysiological investigations in human ${ }^{175}$ and rabbit whole lens preparations revealed that muscarinic, but not nicotinic, receptor activation induces the release of intracellular calcium. So far the only direct determination of muscarinic receptor subtypes in the human lens revealed the presence of $\mathrm{m} 3 \mathrm{mRNA}$ and positive radioligand binding with the $\mathrm{M} 3$ antagonist 4 -DAMP, results matching the physiological evidence. ${ }^{59}$ Still, the elusive role of muscarinic receptors in lens function has to be clarified. Since there is no innervation of the lens, a regulatory effect of muscarinic receptors on cell homeostasis, rather than on neuronal signal transduction, seems probable. Here again an understanding of the interplay with other receptors will finally reveal the precise functions of the muscarinic lenticular system.

\section{Muscarinic receptors influence scleral growth}

One of the most interesting approaches of the long-term application of antimuscarinic drugs is their influence on scleral growth. Especially in the prevention of myopia in humans, the long-term use of antimuscarinic drugs, such as atropine, appears promising. ${ }^{176}$ Experimental studies in chicks have shown a marked reduction of myopic progression, accompanied by ocular elongation, when these eyes were treated with atropine. ${ }^{177,178}$ This elongation stimulus has been shown to be present even in the absence of a connection between the retina and the brain. ${ }^{179}$ It is now believed that a direct stimulus from retinal cells on scleral chondrocytes via the muscarinic system is present. In recent investigations M1 muscarinic receptors have been found to be primarily present in chick scleral chondrocytes when the growth of these cells was monitored in culture. ${ }^{72}$ Several other cell types in humans are growth stimulated by muscarinic acetylcholine receptor agonists and the results of pending clinical trials for the reduction and prevention of myopia through early onset of muscarinic agonists in prone patients are promising. 


\section{Conclusions}

The omnipresence of muscarinic receptors with their various expression patterns in the human eye is a startling finding. The methods employed to determine subtypes have become more sophisticated over recent years and ultimately the quantitative determination of receptor protein expression will yield definitive insights into subtype interactions. In addition to the long-known role of muscarinic receptors on outflow and accommodation regulation in the ciliary apparatus, a wide range of diverse functions has been found. These include the multijunctional sites of neurotransmission in the retina and iris, whose subtype composition is still under investigation. More exploration will be required to clarify the presence of muscarinic signalling in the lens and cornea, where these receptors most likely play a role in the nutritious efforts of these bradytrophic tissues. Here muscarinic signalling seems to be important for growth and regeneration control between cells and less important for fast pace neuronal transmission of signals. The detection of muscarinic signalling in the cellular nucleus is particularly exciting, since gene expression mechanisms might additionally be influenced by intracellular $\mathrm{G}$ protein coupled receptor mechanisms.

The overall picture of the muscarinic system of the eye is continuing to evolve. From the extensive investigations that have been performed it is probable that the ratio and relationship of receptor subtype expression in the eye and other body sites will help to determine their functional roles in a given system.

A new range of muscarinic receptor agonists and antagonists is being tested at present in animal and human models. Their aims are various. Prevention of myopia by muscarinic antagonists is an exciting new aspect. However, fears from toxic side effects of longterm use of substances such as atropine are pushing investigations further into the class of more selective muscarinic antagonists. The complex distribution and expression of all known muscarinic receptor subtypes in the eye can not make us believe in the solely accommodative influence of muscarinic drugs. Reparative functions in the corneal epithelium are enhanced by muscarinic agonists and retinal neurotransmission is influenced by substances interacting with muscarinic receptors. Glaucoma therapy has one of its major strongholds in using indirect muscarinic drugs and here again a more selective influence on uveoscleral outflow is hoped to be gained by increased subtype selectivity of new drugs - and the selectivity towards one receptor subtype will be needed as the picture evolves of an eye densely populated with muscarinic receptors.

The five molecular subtypes of muscarinic receptors are all present in the eye. In distinct structures a different pattern of receptor subtype composition can be found. The role of most of them are not yet understood, which is not surprising since they were first distinguished only just over 10 years ago. Atropine (including its various enduring derivatives) and pilocarpine might soon be accompanied by highly selective muscarinic subtype agonists and antagonists in their clinical applications. The knowledge of the composition of the ocular muscarinic system and its interplay with other receptor signalling systems will therefore help the ophthalmologist in choosing the optimal treatment in the future, since the limits for empirical drug use and development are beginning to be reached.

\section{References}

1. Dale HH. The action of certain esters and ethers of choline and their relation to muscarine. J Pharmacol Exp Ther 1914;6:147-96.

2. Hutchins JB, Hollyfield JG. Autoradiographic identification of muscarinic receptors in human iris smooth muscle. Exp Eye Res 1984;38:515-21.

3. Crook RB, Polansky JR. Neurotransmitters and neuropeptides stimulate inositol phosphates and intracellular calcium in cultured human nonpigmented ciliary epithelium. Invest Ophthalmol Vis Sci 1992;33:1706-16.

4. Abdel-Latiff AA. Cross talk between cyclic AMP and the polyphosphoinositide signalling cascade in iris sphincter and other nonvascular smooth muscle. Proc Soc Exp Biol Med 1996;211:163-77.

5. Weber A. Die Ursache des Glaukoms. Graefes Arch Ophthalmol 1877;23:91.

6. Ringer S, Gould AP. On Jabornadi. Lancet 1875;II:157-9.

7. Loewi O, Navratil E. Über humorale Übertrachbarkeit der Herznervenwirkung. XI. Über den Mechanismus der Vaguswirkung von Physostigmin und Ergotamin. Pflügers Arch 1926;214:689-96.

8. Stedman E, Easson LH. Cholinesterase: an enzyme present in blood-sera from horse. Biochemical J 1932;26:2056-66.

9. Kraitmair H. Die Papavarinwirkung eine Benzylreaktion. Arch Pathol Pharmakol 1932;164:509.

10. Militor H. A comparative study of the effects of five choline compounds used in therapeutics: acetylcholine chloride, acetyl-beta-methylcholine chloride, carbaminoyl choline, ethyl ether beta-methylcholine chloride, carbaminoyl betamethylcholine chloride. J Pharmacol Exp Ther 1936;58:337.

11. Velhagen K. Die Grundlagen der okularen Pharmakologie und Toxikologie des Carbaminocholins. Arch Augenheilk 1933;107:319.

12. Barany EH. The mode of action of miotics on outflow resistance. A study of pilocarpine in the vervet monkey, Cercopithecus ethiops. Trans Ophthalmol Soc UK 1966;86:539-78.

13. Poyer JF, Gabelt BT, Kaufman PL. The effect of muscarinic agonists and selective receptor subtype antagonists on the contractile response of the isolated rhesus monkey ciliary muscle. Exp Eye Res 1994;59:729-36.

14. Sakaki Y, Fukuda Y, Yamashita M. Muscarinic and purinergic $\mathrm{Ca}^{2+}$ mobilisations in the neural retina of early embryonic chick. Int J Dev Neurosci 1996;14:691-9.

15. Lind GJ, Cavanagh HD. Identification and subcellular distribution of muscarinic acetylcholine receptor-related proteins in rabbit cornea and Chinese hamster ovaries. Invest Ophthalmol Vis Sci 1995;36:1492-507.

16. Walkenbach RJ, Ye GS. Muscarinic receptors and their regulation of cyclic GMP in corneal endothelial cells. Invest Ophthalmol Vis Sci 1990;31:702-7.

17. Yamashita M, Fukuda Y. Incurvation of early embryonic neural retina by acetylcholine through muscarinic receptors. Neurosci Lett 1993;163:215-8.

18. Noda M, Takahashi H, Tanabe T, Toyosato M, Furutani Y, Hirose $T$, et al. Primary structure of $\alpha$-subunit precursor of Torpedo californica acetylcholine receptor deduced from cDNA sequence. Nature 1982;299:793-7. 
19. Kubo T, Fukuda K, Mikami A, Maeda A, Takahashi H, Mishina $\mathrm{M}$, et al. Cloning, sequencing and expression of complementary DNA encoding the muscarinic acetylcholine receptor. Nature 1986;323:411-6.

20. Kubo T, Makada A, Sugimoto K, Akiba I, Mikani A, Takahashi $\mathrm{H}$, et al. Primary structure of porcine cardiac muscarinic receptor deduced from the cDNA sequence. FEBS Lett 1987;209:367-72.

21. Hammill OP, Marty A, Neher E, Sakmann B, Sigworth FJ. Improved patch-clamp techniques for high-resolution current recording from cells and cell-free membrane patches. Pflügers Arch 1981;391:85-100.

22. Neher E, Sakmann B. Single channel currents recorded from membrane of denervated frog muscle fibres. Nature 1976;260:799-802.

23. Levey AI. Immunological localization of $\mathrm{m} 1-\mathrm{m} 5$ muscarinic acetylcholine receptors in peripheral tissues and brain. Life Sci 1993;52:441-8.

24. Caulfield MP. Muscarinic receptors: characterisation, coupling and function. Pharmacol Ther 1993;58:319-79.

25. Curtis CAM, Wheatley M, Bansal S, Birdsall NJM, Eveleigh $\mathrm{P}$, Pedder EK, et al. Propylbenzilylcholine mustard labels an acidic acid residue in transmembrane helix 3 of the muscarinic receptor. J Biol Chem 1989;264:489-95.

26. Hammer R, Berrie CP, Birdsall NJM, Burgen ASV, Hulme EC. Pirenzepine distinguishes between different subclasses of muscarinic receptors. Nature 1980;283:90-2.

27. Durieux ME. Muscarinic signalling in the central nervous system: recent developments and anesthetic implications. Anesthesiology 1996;84:173-89.

28. Bonner TI. The molecular basis of muscarinic receptor diversity. Trends Neurosci 1989;12:148-51.

29. Doods HN, Mathy MJ, Davidesko D, van Charldorp KJ, de Jonge A, van Zwieten PA. Selectivity of muscarinic antagonists in radioligand and in vivo experiments for the putative M1, M2 and M3 receptors. J Pharmacol Exp Ther 1987;242:257-62.

30. Eglen RM, Hegde SS, Watson N. Muscarinic receptor subtypes and smooth muscle function. Pharmacol Rev 1996;48:531-65.

31. Caulfield MP, Robbins J, Higashida H, Brown DA. Postsynaptic actions of acetylcholine: the coupling of muscarinic receptor subtypes to neuronal ion channels. Prog Brain Res 1993;98:293-301.

32. Dixon RAF, Sigal IS, Candelore MR, Register RB, Scatergood W, Rands E, et al. Structural features required for ligand binding to the $\beta$-adrenergic receptor. EMBO J 1987;6:3269-75.

33. Kobilka BK, Kobilka TS, Daniel K, Regan JW, Caron MG, Lefkowitz RJ. Chimeric $\alpha_{2}, \beta_{2}$-adrenergic receptors: delineation of domains involved in effector coupling and ligand binding specificity. Science 1988;240:1310-6.

34. Ligett SB, Freedman NJ, Schwinn DA, Lefkowitz RJ. Structural basis for receptor subtype-specific regulation revealed by a chimeric beta $3 /$ beta 2 -adrenergic receptor. Proc Natl Acad Sci USA 1993;90:3665-9.

35. Wess J, Brann MR, Bonner TI. Identification of a small intracellular region of the muscarinic $\mathrm{m} 3$ receptor as a determinant of selective coupling to PI turnover. FEBS Lett 1989;258:133-6.

36. Strader CD, Gaffney T, Sugg EE, Candelore MR, Keys R, Patchett AA, et al. Allele-specific activation of genetically engineered receptors. Biol Chem 1991;266:5-8.

37. Fraser CM, Wang CD, Robinson DA, Gocayne JD, Venter JC. Site-directed mutagenesis of $\mathrm{m} 1$ muscarinic acetylcholine receptors: conserved aspartic acids play important roles in receptor function. Mol Pharmacol 1989;36:840-7.

38. Wess J, Bonner TI, Brann MR. Chimeric $\mathrm{m} 2 / \mathrm{m} 3$ muscarinic receptors: role of carboxyl terminal receptor domains in selectivity of Iigand binding and coupling to phosphoinositide hydrolysis. Mol Pharmacol 1990;38:872-7.
39. Wess J, Gdula D, Brann MR. Site-directed mutagenesis of the $\mathrm{m} 3$ muscarinic receptor: identification of a series of threonine and tyrosine residues involved in agonist but not antagonist binding. EMBO J 1991;10:3729-34.

40. Hammer R, Giachetti A. Muscarinic receptor subtypes: M1 and $\mathrm{M} 2$ biochemical and functional characterisation. Life Sci 1982;31:2991-8.

41. Waelbroeck M, Gillard M, Robberecht P, Christophe J. Muscarinic receptor heterogeneity in rat central nervous system. I. Binding of four selective antagonists to three muscarinic receptor subclasses: a comparison with M2 cardiac muscarinic receptors of the $\mathrm{C}$ type. Mol Pharmacol 1987;32:91-9.

42. Waelbroeck M, Tastenoy M, Camus J, Christophe J. Binding of selective antagonists to four muscarinic receptors $\left(\mathrm{M}_{1}\right.$ to $\mathrm{M}_{4}$ ) in rat forebrain. Mol Pharmacol 1990;38:267-73.

43. Freedman SB, Dawson GR, Iversen LL, Baker R, Hargreaves RJ. The design of novel muscarinic partial agonists that have functional selectivity in pharmacological preparations in vitro and reduced side-effect profile in vivo. Life Sci 1993;52:489-95.

44. Ensinger HA, Doods HN, Immel-Sehr AR, Kuhn FJ, Lambrecht G, Mendla KD, et al. WAL 2014: a muscarinic agonist with preferential neuron-stimulating properties. Life Sci 1993;52:473-80.

45. van Zwieten PA, Doods HN. Muscarinic receptors and drugs in cardiovascular medicine. Cardiovasc Drugs Ther 1995;9:159-67.

46. Brown DA, Adams PR. Muscarinic suppression of a novel voltage-sensitive $\mathrm{K}^{+}$-current in a vertebrate neuron. Nature 1980;283:673-6.

47. Caulfield MP, Jones S, Vallis Y, Buckley NJ, Kim G-D, Milligan G, et al. Muscarinic M-current inhibition via $\mathrm{G7}_{\alpha \mathrm{q} / 11}$ and $\alpha$-adrenoceptor inhibition of $\mathrm{Ca}^{2+}$ current via $\mathrm{G}_{\alpha \mathrm{o}}$ in rat sympathetic neurones. J Physiol (Lond) 1994;477:415-22.

48. Pennefather P, Lancaster B, Adams PR, Nicoll RA. Two distinct Ca-dependent $\mathrm{K}$ currents in bullfrog sympathetic ganglion cells. Proc Natl Acad Sci USA 1985;82:3040-4.

49. Fukuda K, Higashida H, Kubo T, Maeda A, Akiba I, Bujo H, et al. Selective coupling with $\mathrm{K}^{+}$currents of muscarinic acetylcholine receptor subtypes in NG108-15 cells. Nature 1988;335:355-7.

50. Caulfield MP, Brown DA. Pharmacology of the putative $\mathrm{M}_{4}$ muscarinic receptor mediating Ca-current inhibition in neuroblastoma $\times$ glioma hybrid (NG 108-15) cells. Br J Pharmacol 1991;104:39-45.

51. Nardin GF, Zimmerman TJ, Zalta AJ, Felts K. Ocular cholinergic agents. In: Ritch R, Shields BM, Krupins T, editors. The glaucomas. 1st ed. St Louis: CV Mosby, 1989:515-21.

52. Kurachi $Y$, Tung RT, Ito $H$, Nakajima T. G protein activation of cardiac muscarinic $\mathrm{K}^{+}$channels. Prog Neurobiol 1992;39:229-46.

53. Wickman KD, Iniguez-Lluhi JA, Davenport PA, Taussig R, Krapivinsky GB, Linder ME, et al. Recombinant G-protein beta gamma subunits activate the muscarinic-gated atrial potassium channel. Nature 1994;368:255-7.

54. Yamada M, Ho YK, Lee RH, Kontani K, Takahashi K, Katada T, Kurachi Y. Muscarinic $\mathrm{K}^{+}$channels are activated by beta gamma subunits and inhibited by the GDP-bound form of alpha subunit of transducin. Biochem Biophys Res Commun 1994;200:1484-90.

55. Haga K, Haga T. Activation by G protein beta gamma subunits of agonist- or light-dependent phosphorylation of muscarinic acetylcholine receptors and rhodopsin. J Biol Chem 1992;267:2222-7.

56. Morishige K, Takahashi N, Jahangir A, Yamada M, Koyama $\mathrm{H}$, Zanelli JS, et al. Molecular cloning and functional expression of a novel brain-specific inward rectifier potassium channel. FEBS Lett 1994;346:251-6.

57. Brown AM. Membrane-delimited signalling complexes: direct ion channel regulation by $\mathrm{G}$ proteins. J Membr Biol 1993;131:93-104. 
58. Jones SV. Muscarinic receptor subtypes: modulation of ion channels. Life Sci 1993;52:457-64.

59. Gupta N, Drance SM, McAllister R, Prasad S, Rootman J, Cynader MS. Localisation of M3 muscarinic receptor subtype and mRNA in the human eye. Ophthalmic Res 1994;26:207-13.

60. Zhang X, Hernandez MR, Yang H, Erickson K. Expression of muscarinic receptor subtype mRNA in the human ciliary muscle. Invest Ophthalmol Vis Sci 1995;36:1645-57.

61. Gupta N, McAllister R, Drance SM, Rootman J, Cynader MS. Muscarinic receptor M1 and M2 subtypes in the human eye: QNB, pirenzipine, oxotremorine, and AFDX-116 in vitro autoradiography. Br J Ophthalmol 1994;78:555-9.

62. Chen J, Woldemoussie E. Similarity of muscarinic receptor subtype in smooth muscles of cat iris sphincter, ciliary and guinea pig ileum. FASEB J 1988;Suppl: 788.

63. Woldemoussie E, Feldman B. Characterisation of muscarinic receptors in human ciliary and iris smooth muscle cells by ligand binding and biochemical response studies. FASEB J 1988;Suppl: 364.

64. Honkanen RE, Howard EF, Abdel-Latif AA. M3-muscarinic receptor subtype predominates in the bovine iris sphincter smooth muscle and ciliary processes. Invest Ophthalmol Vis Sci 1990;31:590-3.

65. Skorupa AF, Klein WL. Developmentally regulated secreted factors control expression of muscarinic receptor subtypes in embryonic chick retina. J Neurochem 1993;60:2087-97.

66. Hutchins JB. Development of muscarinic acetylcholine receptors in the ferret retina. Brain Res Dev Brain Res 1994;82:45-61.

67. McIntosh H, Blazynski C. Muscarinic receptor stimulated GTPase activity in synaptic membranes from bovine retina. J Neurochem 1992;59:210-5

68. Wax MB, Coca-Prados M. Receptor-mediated phosphoinositide hydrolysis in human ocular ciliary epithelial cells. Invest Ophthalmol Vis Sci 1989;30:1675-9.

69. Mallorga P, Babilon RW, Buisson S, Sugrue MF. Muscarinic receptors of the albino rabbit ciliary process. Exp Eye Res 1989;48:509-22

70. Polansky JR, Zlock D, Brasier A, Bloom E. Adrenergic and cholinergic receptors in isolated non-pigmented ciliary epithelial cells. Curr Eye Res 1985;4:517-22.

71. Colley AM, Cavanah HD. Binding of $\left[{ }^{3} \mathrm{H}\right]$ dihydroalprenolol and $\left[{ }^{3} \mathrm{H}\right]$ quinuclidinyl benzilate to intact cells of cultured corneal epithelium. Metab Pediatr Syst Ophthalmol 1982;6:75-86.

72. Lind GJ, Chew SJ, Marzani D, Wallman J. Muscarinic acetylcholine receptor antagonists inhibit chick scleral chondrocytes. Invest Ophthalmol Vis Sci 1998;39:2217-31.

73. Bonner TI, Buckley NJ, Young AC, Brann MR. Identification of a family of muscarinic acetylcholine receptors. Science 1987;237:527-32.

74. Bursztajn S, Berman SA, Gilbert W. Differential expression of acetylcholine receptor mRNA in nuclei of cultured muscle cells. Proc Natl Acad Sci USA 1989;86:2928-32.

75. Yasuda RP, Ciesla W, Flores LR, Wall SJ, Li M, Satkus SA, et al. Development of antisera selective for $\mathrm{m} 4$ and $\mathrm{m} 5$ muscarinic cholinergic receptors: distribution of $\mathrm{m} 4$ and $\mathrm{m} 5$ receptors in rat brain. Mol Pharmacol 1993;43:149-57.

76. Vilaro MT, Mengod G, Palacios JM. Advances and limitations of the molecular neuroanatomy of cholinergic receptors: the example of multiple muscarinic receptors. Prog Brain Res 1993;98:95-101.

77. Hruska RE, White R, Azari J, Yamamura HI. Muscarinic cholinergic receptors in mammalian retina. Brain Res 1978;148:493-8.

78. Hutchins JB, Hollyfield JG. Acetylcholine receptors in the human retina. Invest Ophthalmol Vis Sci 1985;26:1550-7.

79. Zarbin MA, Wamsley JK, Palacios JM, Kuhar MJ. Autoradiographic localisation of high affinity GABA, benzodiazepine, dopaminergic, adrenergic and muscarinic cholinergic receptors in the rat, monkey and human retina. Brain Res 1986:374:75-92.
80. Vanderheyden P, Ebinger G, Vauquelin G. Characterisation of M1- and M2-muscarinic receptors in calf retina membranes. Vision Res 1988;28:247-50.

81. McKinnon LA, Gunther EC, Nathanson NM. Developmental regulation of the $\mathrm{cm} 2$ muscarinic acetylcholine receptor gene: selective induction by a secreted factor produced by embryonic chick retinal cells. J Neurosci 1998;18:59-69.

82. Moreno-Yanes JA, Mahler HR. Muscarinic cholinergic receptors in goldfish retina. Life Sci 1979;24:1787-91.

83. Neal MJ, Dawson C. Muscarinic cholinergic receptors in rabbit retina. J Pharm Pharmacol 1985;37:60-1.

84. Sugiyama H, Daniels MP, Nirenberg M. Muscarinic acetylcholine receptors of the developing retina. Proc Natl Acad Sci USA 1977;74:5524-8.

85. Salceda R. Muscarinic receptors binding in retinal pigment epithelium during rat development. Neurochem Res 1994;19:1207-10.

86. Klein WL. Biochemistry and regulation of signal transduction by neuronal acetylcholine receptors. Curr Top Cell Regul 1984;24:129-44.

87. Wong RO. Cholinergic regulation of $\left[\mathrm{Ca}^{2+}\right] \mathrm{i}$ during cell division and differentiation in the mammalian retina. J Neurosci 1995;15:2696-706.

88. Friedman Z, Hackett SF, Campochiaro PA. Human retinal pigment epithelial cells possess muscarinic receptors coupled to calcium mobilisation. Brain Res 1988;446:11-6.

89. Yamashita M, Yoshimoto Y, Fukuda Y. Muscarinic acetylcholine responses in the early embryonic chick retina. J Neurobiol 1994;25:1144-53.

90. Siman RG, Klein WL. Differential regulation of muscarinic and nicotinic receptors by cholinergic stimulation in cultured avian retina cells. Brain Res 1983;262:99-108.

91. Qu ZX, Fertel R, Neff NH, Hadjiconstantinou M. Pharmacological characterisation of muscarinic receptors mediating inhibition of adenylate cyclase activity in the rat retina. J Pharmacol Exp Ther 1988;246:839-42.

92. Jardon B, Bonaventure N, Scherrer E. Possible involvement of cholinergic and glycinergic amacrine cells in the inhibition exerted by the ON retinal channel on the OFF retinal channel. Eur J Pharmacol 1992;210:201-7.

93. Negishi K, Kato S, Teranishi T, Laufer M. An electrophysiological study on the cholinergic system in the carp retina. Brain Res 1978;148:85-93.

94. Baughman RW, Bader CR. Biochemical characterisation and cellular localisation of the cholinergic system in the chicken retina. Brain Res 1977;138:469-85.

95. Masland RH, Mills JW, Cassidy C. The functions of acetylcholine in the rabbit retina. Proc R Soc Lond Ser B 1984;223:121-39.

96. Linn DM, Massey SC. Homocysteate-evoked release of acetylcholine from the rabbit retina. J Neurochem 1996;66:153-60.

97. Neal MJ, Cunningham JR, Hutson PH, Semark JE. Calcium dependent release of acetylcholine and gammaaminobuytric acid from the rabbit retina. Neurochem Int 1992;20:43-53.

98. Nilsson SF. The uveoscleral outflow routes. Eye 1997;11:149-54.

99. Farahbaksh NA, Cilluffo MC. Synergistic increase in $\mathrm{Ca}^{2+}$ produced by $\mathrm{A} 1$ adenosine and muscarinic receptor activation via a pertussis-toxin-sensitive pathway in epithelial cells of the rabbit ciliary body. Exp Eye Res 1997;64:173-9.

100. Gil DW, Krauss HA, Bogardus AM, Woldemussie E. Muscarinic receptor subtypes in human iris-ciliary body measured by immunoprecipitation. Invest Ophthalmol Vis Sci 1997;38:1434-42.

101. Barany EH. Muscarinic subsensitivity without receptor change in monkey ciliary muscle. Br J Pharmacol 1985;84:193-8.

102. Gilmartin B, Hogan RE. The relationship between tonic accommodation and ciliary muscle innervation. Invest Ophthalmol Vis Sci 1985;26:1024-8. 
103. Kaufman PL, Barany EH. Residual pilocarpine effects on outflow facility after ciliary muscle disinsertion in the cynomolgus monkey. Invest Ophthalmol 1976;15:558-61.

104. Kaufman PL, Barany EH. Subsensitivity to pilocarpine of the aqueous outflow system in monkey eyes after topical anticholinestersae treatment. Am J Ophthalmol 1976;82:883-91.

105. Gabelt BT, Kaufman PL. Inhibition of aceclidine-stimulated outflow facility, accommodation and miosis in rhesus monkeys by muscarinic receptor subtype antagonists. Exp Eye Res 1994;58:623-30.

106. Hubbard WC, Kee C, Kaufman PL. Aceclidine effects on outflow facility after ciliary muscle disinsertion. Ophthalmologica 1996;210:303-7.

107. Poyer JF, Kaufman PL, Flugel C. Age does not affect contractile responses of the isolated rhesus monkey ciliary muscle to muscarinic agonists. Curr Eye Res 1993;12:413-22.

108. Erickson-Lamy K, Schroeder A. Dissociation between the effect of aceclidine on outflow facility and accommodation. Exp Eye Res 1990;50:143-7.

109. Flugel C, Barany EH, Lutjen-Drecoll E. Histochemical differences within the ciliary muscle and its function in accommodation. Exp Eye Res 1990;50:219-26.

110. Hoskins HD Jr, Kass MA. Cholinergic drugs. In: BeckerSchaffer's diagnosis and therapy of glaucoma. 6 th ed. St Louis: CV Mosby, 1989;420-34.

111. Fechner PU, Teichmann KD, Weyrauch W. Accommodative effects of aceclidine in the treatment of glaucoma. Am J Ophthalmol 1975;79:104-6.

112. Keren G, Treister G. Effect of aceclidine $(+)$ isomer and pilocarpine on the intraocular pressure decrease and the miosis in glaucomatous eyes: effect on accommodation in normal eyes of young subjects. Ophthalmologica 1980;180:181-7.

113. Lieberman TW, Leopold IH. The use of aceclydine in the treatment of glaucoma: its effect on intraocular pressure and facility of aqueous humor outflow as compared to that of pilocarpine. Am J Ophthalmol 1967;64:405-15.

114. Croft MA, Kaufman PL, Erickson-Lamy K, Polansky JR. Accommodation and ciliary muscle muscarinic receptors after echothiophate. Invest Ophthalmol Vis Sci 1991;32:3288-97.

115. Erickson-Lamy KA, Polansky JR, Kaufman PL, Zlock DM. Cholinergic drugs alter ciliary muscle response and receptor content. Invest Ophthalmol Vis Sci 1987;28:375-83.

116. Gabelt BT, Kaufman PL. Inhibition of outflow facility and accommodative and miotic responses to pilocarpine in rhesus monkeys by muscarinic receptor subtype antagonists. J Pharmacol Exp Ther 1992;263:1133-9.

117. Gabelt BT, Kaufman PL, Polansky JR. Ciliary muscle muscarinic binding sites, choline acetyltransferase, and acetylcholinesterase in aging rhesus monkeys. Invest Ophthalmol Vis Sci 1990;31:2431-6.

118. Pang IH, Matsumoto S, Tamm E, DeSantis L. Characterisation of muscarinic receptor involvement in human ciliary muscle cell function. J Ocul Pharmacol 1994;10:125-36.

119. Daniele E, Villani G, Lograno MD. Effects of phorbol ester on carbachol-induced contraction in bovine ciliary muscle: possible involvement of protein kinase C. Eur J Pharmacol 1997;330:247-56

120. Wiederholt M, Schafter R, Wagner U, Lepple-Wienhues A. Contractile response of the isolated trabecular meshwork and ciliary muscle to cholinergic and adrenergic agents. Ger J Ophthalmol 1996;5:146-53.

121. Fuder H. Functional consequences of prejunctional receptor activation or blockade in the iris. J Ocular Pharmacol 1994;10:109-23.

122. Lograno MD, Paoletti R. Human intraocular smooth muscles: role of receptors in aqueous humour dynamics. Pharmacol Res 1989;21:683-99.

123. Jumblatt JE, Hackmiller RC. M2-type muscarinic receptors mediate prejunctional inhibition of norepinephrine release in the human iris-ciliary body. Exp Eye Res 1994;58:175-80.
124. Kaufman PL. Parasympathetic denervation of the ciliary muscle following retinal photocoagulation. Trans Am Ophthalmol Soc 1990;88:513-53.

125. Lutjen-Drecoll E, Kaufman PL. Biomechanics of echothiophate-induced anatomic changes in monkey aqueous outflow system. Graefes Arch Clin Exp Ophthalmol 1986;224:564-75.

126. Shade DL, Clark AF, Pang IH. Effects of muscarinic agents on cultured human trabecular meshwork cells. Exp Eye Res 1996;62:201-10.

127. Kaufman PL. Mechanisms of actions of the cholinergic drugs in the eye. In: Drance SM, Neufeld AN, editors. Glaucoma. 1st ed. Orlando: Grune and Stratton, 1984;295-327.

128. Jumblatt JE, North GT, Hackmiller RC. Muscarinic cholinergic inhibition of adenylate cyclase in the rabbit irisciliary body and ciliary epithelium. Invest Ophthalmol Vis Sci 1990;31:1103-8.

129. Yousufzai SY, Honkanen RE, Abdel-Latif AA. Muscarinic cholinergic induced subsensitivity in rabbit iris-ciliary body: effects on myo-inositol triphosphate accumulation, arachidonate release, prostaglandin synthesis, and contraction. Invest Ophthalmol Vis Sci 1987;28;1631-8.

130. Neufeld AH. The mechanisms of action of adrenergic drugs in the eye. In: Glaucoma. Orlando: Grune and Stratton, 1984;277-301.

131. Sears M, Mead A. A major pathway for the regulation of intraocular pressure. Int Ophthalmol 1983;6:201-12.

132. Suzuki $Y$, Nakano T, Sears M. Calcium signals from intact rabbit ciliary epithelium observed with confocal microscopy. Curr Eye Res 1997;16:166-75.

133. Hasegawa N, Imaizumi Y, Watanabe M. Parasympathetic denervation supersensitivity in the rat iris sphincter muscle: an in vitro study. Jpn J Pharmacol 1987;43:143-51.

134. Akesson C, Swanson C, Patil PN. Muscarinic receptors of rabbit irides. Naunyn Schmiedebergs Arch Pharmacol 1983;322:104-10.

135. Karlsen RL. Muscarinic receptor binding and the effect of atropine on the guinea-pig iris. Exp Eye Res 1978;27:577-83.

136. Kloog Y, Heron DS, Korczyn AD, Sachs DI, Sokolovsky M. Muscarinic acetylcholine receptors in albino rabbit irisciliary body. Mol Pharmacol 1979;15:581-7.

137. Kloog Y, Sachs DI, Korczyn AD, Heron DS, Sokolovsky M. Muscarinic acetylcholine receptors in cat iris. Biochem Pharmacol 1979;28:1505-11.

138. Olsen JS, Neufeld AH. The rabbit cornea lacks cholinergic receptors. Invest Ophthalmol Vis Sci 1979;18:1216-25.

139. Sachs DI, Kloog Y, Korczyn AD, Heron DS, Sokolovsky M. Denervation, supersensitivity and muscarinic receptors in the cat iris. Biochem Pharmacol 1979;28:1513-8.

140. Kaumann AJ, Hennekes R. The affinity of atropine for muscarine receptors in human sphincter pupillae. Naunyn Schmiedebergs Arch Pharmacol 1979;306:209-11.

141. Hagan JJ, van der Heijden B, Broekkamp CL. The relative potencies of cholinomimetics and muscarinic antagonists on the rat iris in vivo: effects of $\mathrm{pH}$ on potency of pirenzepine and telenzepine. Naunyn Schmiedebergs Arch Pharmacol 1988;338:476-83.

142. Patil PN. Reactivity of human iris-sphincter to muscarinic drugs in vitro. Naunyn Schmiedebergs Arch Pharmacol 1992;346:614-9.

143. Konno F, Takayanagi I. Muscarinic acetylcholine receptors in the rabbit ciliary body smooth muscle: spare receptors and threshold phenomenon. Jpn J Pharmacol 1985;38:91-9

144. Bognar IT, Baumann B, Dammann F, Knoll B, Meincke M, Pallas S, et al. M2 muscarinic receptors on the iris sphincter muscle differ from those on iris noradrenergic nerves. Eur J Pharmacol 1989;163:263-74.

145. Bognar IT, Altes U, Beinhauer C, Kessler I, Fuder H. A muscarinic receptor different from the M1, M2, M3 and M4 subtypes mediates the contraction of the rabbit iris sphincter. Naunyn Schmiedebergs Arch Pharmacol 1992;345:611-8. 
146. Bognar IT, Pallas S, Fuder H, Muscholl E. Muscarinic inhibition of $\left[{ }^{3} \mathrm{H}\right]$ noradrenaline release on rabbit iris in vitro: effects of stimulation conditions on intrinsic activity of methacholine and pilocarpine. Br J Pharmacol 1988;94:890-900

147. Honkanen RE, Abdel-Latif AA. Characterisation of cholinergic muscarinic receptors in the rabbit iris. Biochem Pharmacol 1988:37:2575-83.

148. Bognar IT, Wesner MT, Fuder H. Muscarine receptor types mediating autoinhibition of acetylcholine release and sphincter contraction in the guinea-pig iris. Naunyn Schmiedebergs Arch Pharmacol 1990;341:22-9.

149. Masuda Y, Yamahara NS, Tanaka M, Ryang S, Kawai T, Imaizumi $Y$, et al. Characterisation of muscarinic receptors mediating relaxation and contraction in the rat iris dilator muscle. Br J Pharmacol 1995;114:769-76.

150. Shiraishi K, Takayanagi I. Subtype of muscarinic receptors mediating relaxation and contraction in the rat iris dilator smooth muscle. Gen Pharmacol 1993;24:139-42.

151. Yamahara NS, Tanaka M, Imaizumi Y, Watanabe M. Pertussis toxin-sensitive muscarinic relaxation in the rat iris dilator muscle. Br J Pharmacol 1995;114:777-84.

152. Fuder H, Schopf J, Unckell J, Wesner MT, Melchiorre C, Tacke $\mathrm{R}$, et al. Different muscarine receptors mediate the prejunctional inhibition of $\left[{ }^{3} \mathrm{H}\right]$ noradrenaline release in rat or guinea-pig iris and the contraction of the rabbit iris sphincter muscle. Naunyn Schmiedebergs Arch Pharmacol 1989;340:597-604.

153. Abdel-Latif AA, Howe PH, Akhtar RA. Muscarinic-receptor induced myo-inositol trisphosphate accumulation, myosin light chain phosphorylation and contraction in the rabbit iris sphincter smooth muscle. Prog Clin Biol Res 1987;249:119-32.

154. Akhtar RA, Honkanen RE, Howe PH, Abdel-Latif AA. M2 muscarinic receptor subtype is associated with inositol trisphosphate accumulation, myosin light chain phosphorylation and contraction in sphincter smooth muscle of rabbit iris. J Pharmacol Exp Ther 1987;243:624-32

155. Woldemussie E, Feldmann BJ, Chen J. Characterisation of muscarinic receptors in cultured human iris sphincter and ciliary smooth muscle cells. Exp Eye Res 1993;56:385-92.

156. Ding KH, Husain S, Akhtar RA, Isales CM, Abdel-Latif AA. Inhibition of muscarinic-stimulated polyphosphoinositide hydrolysis and $\mathrm{Ca}^{2+}$ mobilisation in cat iris sphincter smooth muscle cells by cAMP-elevating agents. Cell Signal 1997;9:411-21.

157. Tachado SD, Virdee K, Akhtar RA, Abdel-Latif AA. M3 muscarinic receptors mediate an increase in both inositol trisphosphate production and cyclic AMP formation in dog iris sphincter smooth muscle. J Ocul Pharmacol 1994;10:137-47.

158. Abdel-Latif AA. Polyphosphoinositides, generation of second messengers, myosin light chain phosphorylation and contraction in rabbit iris sphincter smooth muscle. Mol Cell Biochem 1988;82:125-30.

159. von Bruecke H, Hellauer HF, Umrath K. Acetylcholin und Inhalt der Hornhaut und seine Beziehungen zur Nervenversorgung. Ophthalmologica 1949;117:19-35.

160. Williams JD, Cooper JR. Acetylcholine in bovine corneal epithelium. Biochem Pharmacol 1965;14:1286-9.

161. Fitzgerald GG, Cooper JR. Acetylcholine as a possible sensory mediator in rabbit corneal epithelium. Biochem Pharmacol 1971;20:2741-8.
162. Sigelman S, Friedenwald JS. Mitotic and wound healing activities of the corneal epithelium: effects of sensory denervation. Arch Ophthalmol 1954;54:46-57.

163. Walkenbach RJ, Ye GS. Muscarinic cholinoceptor regulation of cyclic guanosine monophosphate in human corneal epithelium. Invest Ophthalmol Vis Sci 1991;32:610-5.

164. Walkenbach RJ, Ye GS, Boney F, Dueker DK. Muscarinic cholinoceptors in native and cultured human corneal endothelium. Curr Eye Res 1993;12:155-62.

165. Cavanagh HD, Colley AM. Cholinergic, adrenergic, and $\mathrm{PGE}_{1}$ effects on cyclic nucleotides and growth in cultured corneal epithelium. Metab Pediatr Syst Ophthalmol 1982;6:63-74.

166. Divecha N, Banfic H, Irvine RF. The polyphosphoinositide cycle exists in the nuclei of Swiss 3T3 cells under the control of a receptor (for IGF-I) in the plasma membrane, and stimulation of the cycle increases nuclear diacylglycerol and apparently induces translocation of protein kinase $C$ to the nucleus. EMBO J 1991;10:3207-14.

167. Divecha N, Rhee SG, Letcher AJ, Irvine RF.

Phosphoinositide signalling enzymes in rat liver nuclei: phosphoinositidase $C$ isoform beta 1 is specifically, but not predominantly, located in the nucleus. Biochem J 1993;289:617-20.

168. Lind GJ, Cavanagh HD. Nuclear muscarinic acetylcholine receptors in corneal cells from rabbit. Invest Ophthalmol Vis Sci 1993;34:2943-52.

169. Payrastre B, Nievers M, Boonstra J, Breton M, Verkleij AJ, Van Bergen en Henegouwen PM. A differential location of phosphoinositide kinases, diacylglycerol kinase, and phospholipase $\mathrm{C}$ in the nuclear matrix. J Biol Chem 1992;267:5078-84.

170. Michon J Jr, Kinoshita JH. Experimental miotic cataract. I Effects of miotics on lens structure, cation content, and hydration. Arch Ophthalmol 1968;79:79-86.

171. Michon J Jr, Kinoshita JH. Cholinesterase in the lens. Arch Ophthalmol 1967;77:804-8.

172. Shaffer RN, Hetherington J Jr. Anticholinesterase drugs and cataracts. Am J Ophthalmol 1966;62:613-8.

173. Fraser PJ, Duncan G, Tomlinson J. Effect of a cholinesterase inhibitor on salmonid lens: a possible cause for the increased incidence of cataract in salmon Salmo salar (L.). Exp Eye Res 1989;49:293-8.

174. Philipson B, Kaufman PL, Fagerholm P, Axelsson U, Barany $\mathrm{EH}$. Echothiophate cataracts in monkeys: electron microscopy and microradiography. Arch Ophthalmol 1979;97:340-6.

175. Alvarez LJ, Candia OA, Zamudio AC. Acetylcholine modulation of the short-circuit current across the rabbit lens. Exp Eye Res 1995;61:129-40.

176. Bedrossian RH. The effect of atropine on myopia. Ophthalmology 1979;86:713-7.

177. McBrien NA, Moghaddam HO, Reeder AP. Atropine reduces experimental myopia and eye enlargement via a nonaccommodative mechanism. Invest Ophthalmol Vis Sci 1993;34:205-15.

178. Stone RA, Lin T, Laties AM. Muscarinic antagonist effects on experimental chick myopia. Exp Eye Res 1991;52:755-8.

179. Troilo D, Gottlieb MD, Wallman J. Visual deprivation causes myopia in chicks with optic nerve section. Curr Eye Res 1987;6:993-9. 